\title{
Activins regulate $17 \beta$-hydroxysteroid dehydrogenase type I transcription in murine gonadotrope cells
}

\author{
Beata Bak*, Laura Carpio*, Jinjing L Kipp", Pankaj Lamba, Ying Wang, Ren-Shan Ge², Matthew P Hardy ${ }^{2,+}$, \\ Kelly E Mayo ${ }^{1}$ and Daniel J Bernard \\ Department of Pharmacology and Therapeutics, McGill University, 3655 Promenade Sir-William-Osler, Room 1315, Montreal, QC, Canada H3G 1Y6 \\ ${ }^{1}$ Department of Biochemistry, Molecular Biology and Cell Biology, Northwestern University, Evanston, Illinois 60208, USA \\ ${ }^{2}$ Center for Biomedical Research, Population Council, New York, New York 10021, USA \\ (Correspondence should be addressed to D J Bernard; Email: daniel.bernard@mcgill.ca) \\ *(B Bak and L Carpio contributed equally to this work) \\ ${ }^{+} \mathrm{MPH}$ is now deceased
}

\begin{abstract}
Activins are pleiotropic members of the TGF $\beta$ superfamily and were initially characterized based on their abilities to stimulate FSH synthesis and secretion by gonadotrope cells of the anterior pituitary gland. Here, we identified the gene encoding the steroidogenic enzyme, 17 $\beta$-hydroxysteroid dehydrogenase type I (17ß-HSD1; Hsd17b1), as an activinresponsive gene in immortalized gonadotrope cells, L $\beta \mathrm{T} 2$. $17 \beta-H S D 1$ catalyzes the conversion of estrone to the more active $17 \beta$-estradiol, and activin A stimulated an increase in this enzymatic activity in these cells. We demonstrated that activins signaled via the type I receptor, activin receptor-like kinase (ALK4), and the intracellular signaling protein,
\end{abstract}

SMAD2, to regulate $H s d 17 b 1$ transcription in immediateearly fashion. Critical cis-elements, including a minimal SMAD-binding element, were mapped to within $100 \mathrm{bp}$ of the start of transcription. Activin/ALK4 signaling also regulated $H s d 17 b 1$ transcription in both immortalized and primary cultured murine granulosa cells. The promoter regions mediating basal and activin/ALK4-regulated promoter activity were generally conserved across the different cell types. The data show that activin A rapidly regulates $H s d 17 b 1$ transcription in gonadotrope and granulosa cells and may thereby regulate local $17 \beta$-estradiol synthesis.

Journal of Endocrinology (2009) 201, 89-104

\section{Introduction}

Activins, members of the transforming growth factor- $\beta$ (TGF $\beta$ ) superfamily, were initially purified and characterized based on their abilities to selectively stimulate FSH secretion by primary pituitary cell cultures (Ling et al. 1986a,b, Vale et al. 1986). The ligands were subsequently shown to act largely in an autocrine/paracrine fashion in gonadotrope cells to regulate transcription of the FSH $\beta$ (Fshb) subunit gene, the rate-limiting step in the synthesis of dimeric FSH (Attardi \& Miklos 1990, Weiss et al. 1995, Pernasetti et al. 2001, Suszko et al. 2003). Activins' actions are not limited to the pituitary as they play important pleiotropic roles in a variety of tissues during development and in different physiological and pathophysiological processes in adulthood (Matzuk et al. 1996, Reis et al. 2004, Werner \& Alzheimer 2006). Most recently, activins were implicated in maintaining pluripotency of the human embryonic stem cells in culture (Beattie et al. 2005, Xu et al. 2008).

In addition to their effects on FSH synthesis, activins also regulate transcription of other genes in the gonadotrope cells, including the type I GnRH receptor (Gnrhr) and the activin bioneutralizing protein, follistatin (FST) (Fernandez-Vazquez et al. 1996, Blount et al. 2008). These effects provide a means for activins to regulate gonadotropin synthesis and secretion indirectly, in addition to their direct effects on the Fshb subunit. To gain a better appreciation for the range of activin effects on gonadotrope cell function, we examined the patterns of gene expression in control and activin A-treated immortalized murine gonadotrope cells, L $\beta T 2$, using cDNA microarrays. Similar analyses have recently been reported by others (Mazhawidza et al. 2006, Zhang et al. 2006).

Consistent with one of the previous reports (Zhang et al. 2006), we observed a marked upregulation of the mRNA encoding the steroidogenic enzyme 17 $\beta$-hydroxysteroid dehydrogenase type I (17 $\beta$-HSD1; Hsd17b1) in these cells. Activin A was previously shown to stimulate $H s d 17 b 1$ mRNA expression in isolated rat granulosa cells (Ghersevich et al. 2000). Because 17 $\beta$-HSD1 catalyzes the conversion of estrone $\left(\mathrm{E}_{1}\right)$ to the more biologically active estrogen, $17 \beta$ estradiol $\left(E_{2}\right)$, the data suggested a mechanism whereby activins might alter gonadotrope sensitivity to estrogen feedback. Indeed, activin $A$ was reported to enhance $E_{1}$ regulation of an estrogen-responsive promoter-reporter in 
L $\beta$ T2 cells (Zhang et al. 2006). Here, we investigated the intracellular signaling mechanisms through which activin A regulates $H s d 17 b 1$ transcription in L $\beta \mathrm{T} 2$ cells and then examined the conservation of these mechanisms in immortalized and primary murine granulosa cells.

\section{Materials and Methods}

\section{Reagents}

Activins A, B, and $\mathrm{AB}$ were purchased from R\&D Systems (Minneapolis, MN, USA). Inhibin A was from DSL (Webster, TX, USA). Follistatin-288 was either purchased from R\&D or generously provided by Dr Tom Thompson (University of Cincinnati). SB431542 and cycloheximide were from Sigma. SMAD2, SMAD4, and $\mathrm{C} / \mathrm{EBP} \alpha$ antibodies were purchased from Santa Cruz Biotechnology Inc. The phospho-SMAD2 antibody was from Cell Signaling Technology (Danvers, MA, USA). SMAD4 and control siRNAs were from Dharmacon. DMEM, Dulbecco's PBS, and gentamycin were from Wisent Bioproducts (St. Bruno, QC, Canada). DMEM/F12 was from Fisher-Hyclone (Logan, UT, USA). FBS, Trizol, and Lipofectamine 2000 were from Invitrogen (Carlsbad, CA, USA).

\section{Constructs}

To generate murine Hsd17b1 promoter-reporters, NIH3T3 cell genomic DNA was subjected to PCR using Pfu Taq (Stratagene, Cedar, Greek, TX, USA) and the five sense primers listed in Table 1, each with the $-13 /+9$ antisense primer. The start of the transcription $(+1)$ was determined by comparing available murine $H s d 17 b 1$ cDNA (GenBank accession \# NM_010475) and genomic sequences (Chr. 11;
GenBank accession \# AC069014). Mlu1 and Xho1 restriction sites (underlined) were included in the primers for cloning purposes. PCR products and the destination vector, pGL3Basic (Promega), were digested with Mlu1 and Xho1 and ligated with T4 DNA ligase (Promega). The $-64 /+9$ Hsd17b1 reporter was generated using - 106/ + 9 Hsd17b1luc as PCR template. Mutant $H s d 17 b 1$ reporters were produced by PCR-based site-directed mutagenesis of the -106/+9 Hsd17b1-luc construct using the mutagenesis primers in Table 1 and the QuikChange protocol (Stratagene). SMAD2 and SMAD3 shRNAs, and SMAD2, SMAD3, and activin receptor-like kinase (ALK4)-T206D expression vectors were described previously (Bernard 2004, Lamba et al. 2006). pcDNA3.0 was from invitrogen. The D268A mutation in ALK4-T206D was introduced by sitedirected mutagenesis.

\section{Cell line cultures}

L $\beta$ T 2 cells were provided by Dr Pamela Mellon (University of California, San Diego, CA, USA) and were cultured in (DMEM, Wisent Bioproducts) supplemented with 10\% (v/v) FBS (Invitrogen) and $4 \mu \mathrm{g} / \mathrm{ml}$ gentamycin (Wisent) at $37{ }^{\circ} \mathrm{C} / 5 \% \mathrm{CO}_{2}$. For transfection experiments, cells were seeded in 24 -well plates at a density of $2 \cdot 5 \times 10^{5}$ cells/well $\sim 72 \mathrm{~h}$ prior to transfection. For RNA extractions, cells were plated in 6-well plates at a density of $0 \cdot 5-1 \times 10^{6}$ cells/well and allowed to grow to $80-90 \%$ confluence before treatment. For nuclear protein extractions, cells were seeded in $10 \mathrm{~cm}$ dishes and treated when 70-100\% confluent. KK-1 cells were provided by Dr Stephen Franks (Imperial College of London) and were cultured in DMEM/F12 supplemented with $10 \%$

Table 1 PCR primers, and gel shift and DNA-affinity pull-down (DNAP) probe sequences

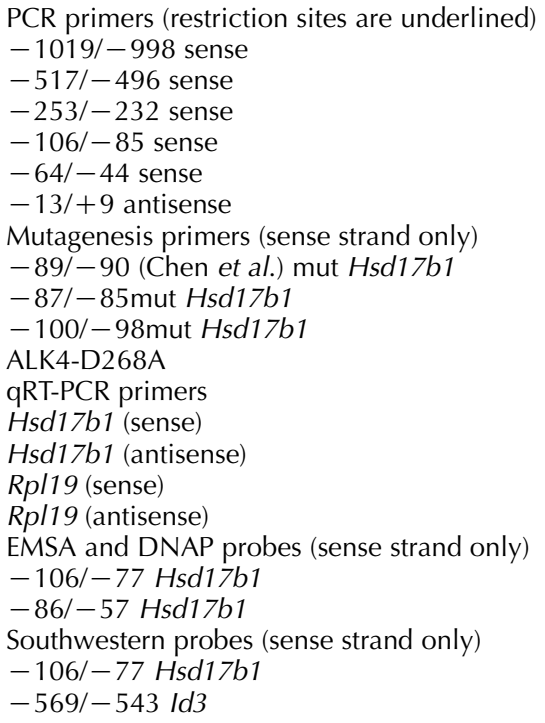

5' GCGACGCGTGACCTCTCCAAGAAGATCTTCC $3^{\prime}$

$5^{\prime}$ GCGACGCGTAACCTCAGCTCCATAAGGAGTC 3'

5' GCGACGCGTAACCTACCGATCTAGCTGCTAC 3'

5' GCGACGCGTCCTTGAGATTGCCAGCAGACAC $3^{\prime}$

$5^{\prime}$ GCGACGCGTTGGGCAGGAGCAGAGCCAAGC $3^{\prime}$

$5^{\prime}$ GCGCTCGAGAGCAAGCAAGCGAGCATGAAGG 3'

$5^{\prime}$ CCTTGAGATTGCCAGCCTACACAACAAGGGGTGG $3^{\prime}$

5' GAGATTGCCAGCAGAGGGAACAAGGGGTGGGG 3'

5' CTTACGCGTCCTTGATCGTGCCAGCAGACACAAC $3^{\prime}$

5'TTGGGTTTATTGCTGCTGCCAATAAAGACAATGGCACC $3^{\prime}$

5' GTTATGAGCAAGCCCTGAGC $3^{\prime}$

5' AAGCGGTTCGTGGAGAAGTA 3'

$5^{\prime}$ CGGGAATCCAAGAAGATTGA $3^{\prime}$

5' TTCAGCTTGTGGATGTGCTC $3^{\prime}$

$5^{\prime}$ CCTTGAGATTGCCAGCAGACACAACAAGGG 3'

$5^{\prime}$ ACAACAAGGGGTGGGCCGCTGTGGGCAGG 3'

5' CCTTGAGATTGCCAGCAGACACAACAAGGG 3'

5' CATTGTAACCTCAGCTTCACCGCAAT 3' 
FBS, and $4 \mu \mathrm{g} / \mathrm{ml}$ gentamycin at $37^{\circ} \mathrm{C} / 5 \% \quad \mathrm{CO}_{2}$. For transfection experiments, cells were seeded in 24-well plates at a density of $10^{5}$ cells/well, $\sim 24 \mathrm{~h}$ prior to transfection.

\section{Transfections and luciferase assays in cell lines}

Reporter and expression plasmids were transfected at 450 and $100 \mathrm{ng} /$ well respectively, using Lipofectamine 2000 as per the manufacturer's instructions. Total amounts of DNA were balanced across treatments. Approximately $24 \mathrm{~h}$ post transfection, cells were washed with PBS and then treated with $25 \mathrm{ng} / \mathrm{ml}$ activin A, B, or AB in DMEM or with DMEM alone. For inhibitor experiments, $10 \mu \mathrm{M}$ SB431542 was introduced $30 \mathrm{~min}$ prior to treatment with activins. For timecourse experiments, activin A was introduced at the indicated number of hours, prior to protein extraction. After the treatments, cells were washed with cold PBS and proteins were extracted using $100 \mu \mathrm{l} /$ well of $1 \times$ passive lysis buffer (Promega). Twenty microliters of each sample were assayed for luciferase activity using an Orion II Microplate Luminometer (Berthold Detection Systems, Bad Wildbad, Germany). All experiments were performed in duplicate or triplicate a minimum of three times.

\section{Thin layer chromatography}

17 $\beta$-HSD1 activity was measured using a method based on that previously described in Singh \& Reed (1991). In brief, L $\beta$ T2 cells were plated in 24 well plates and cultured in growth media until $70-80 \%$ confluent. Cells were then washed and incubated overnight in media plus 2\% (v/v) FBS in the presence or absence of $25 \mathrm{ng} / \mathrm{ml}$ activin A. The intact monolayers were then incubated at $37^{\circ} \mathrm{C}$ with $5 \mathrm{nM}$ tritiated $\left[6,7-{ }^{3} \mathrm{H}\right]$ E1 $(50 \mathrm{Ci} / \mathrm{mmol}$, NEN-Perkin-Elmer, Waltham, MA, USA) for the indicated times. Blank incubations were carried out in parallel by incubating labeled steroid in cell-free wells. After incubation, $0.5 \mathrm{ml}$ of the medium was removed and diethyl ether $(2 \mathrm{ml})$ was used to extract steroids from the medium. The diethyl ether was transferred to a new glass tube and the organic layer was dried under nitrogen. Steroids were separated chromatographically on thin layer plates (Silica Gel IB-F, JT Baker, Phillipsburg, NJ, USA) in dichloromethane/ ethyl acetate $(4: 1, \mathrm{v} / \mathrm{v})$, and the radioactivity was measured using a scanning radiometer (System AR2000, Bioscan Inc., Washington, DC, USA). The percentage conversion of $E_{1}$ to $\mathrm{E}_{2}$ was calculated by dividing the radioactive counts identified as $E_{2}$ by the total counts associated with $E_{1}$ plus $E_{2}$. All treatments were performed in triplicate and the experiment was repeated at least twice.

\section{Quantitative RT-PCR}

L $\beta$ T2 cells were washed with PBS and then treated with serum-free DMEM $\pm 25 \mathrm{ng} / \mathrm{ml}$ activin $\mathrm{A}$ for the indicated periods of time. When included, cycloheximide $(5 \mu \mathrm{g} / \mathrm{ml})$ or SB431542 $(10 \mu \mathrm{M})$ was applied for 15 or $30 \mathrm{~min}$ respectively, prior to the addition of activin A. The cells were then washed with PBS and total RNA was extracted using Trizol following the manufacturer's instructions. Concentrations were determined by spectrophotometry. One microgram of each RNA sample was DNased using RQ1 DNase, and reverse transcribed into cDNA using $50 \mathrm{ng}$ random hexamer primers and Moloney murine leukemia virus reverse transcriptase (Promega). Each reverse transcription reaction was diluted 1:10 for PCR analysis. A relative five-point standard curve was prepared using 1:10 serial dilutions of cDNA from a sample with high Hsd17b1 expression. The PCR was performed using Platinum SYBR Green qPCR SuperMix UDG (Invitrogen) and $0.4 \mathrm{pmol}$ of each primer (see Table 1) on a Corbett Rotor-Gene 6200 HRM, as per Invitrogen's real-time cycling protocol. PCR primers were designed to span intron sequences to distinguish amplified mRNA (cDNA) from contaminating genomic DNA. Melting curve analysis confirmed amplification of a single amplicon. The Hsd17b1 primers had an efficiency between $0 \cdot 7$ and $1 \cdot 0$ for all experiments. All samples were analyzed in triplicate, and each experiment was performed at least twice. Hsd17b1 transcripts levels were normalized by a similar qPCR analysis of the housekeeping gene ribosomal protein L19 (Rpl19) on the same cDNA samples, but run in separate tubes. The Rpl19 primers are shown in Table 1 and amplified with an efficiency of $0 \cdot 7-1 \cdot 0$.

\section{Electrophoretic mobility shift assays}

L $\beta$ T2 cells were washed with PBS and treated with serumfree DMEM $\pm 25 \mathrm{ng} / \mathrm{ml}$ activin A for the indicated periods of time. The cells were then washed with cold PBS, and nuclear protein lysates were prepared as described previously (Lamba et al. 2006). Protein concentrations were measured by Bradford assay (Biorad). Following the collection of nuclear extracts, gel shift experiments were performed as previously described (Lamba et al. 2006), with minor modifications to the protocol. Two micrograms of nuclear proteins were incubated with $50 \mathrm{fmol}$ of ${ }^{32} \mathrm{P} \gamma$-ATP (Perkin-Elmer) endlabeled double-stranded probes corresponding to $-106 /-77$ and $-86 /-57$ (Table 1) of the murine Hsd17b1 promoter for $20 \mathrm{~min}$ at room temperature. Binding reactions were incubated with the following components: $25 \mathrm{mM}$ HEPES (pH 7-2), $150 \mathrm{mM} \mathrm{KCl,} 5 \mathrm{mM}$ dithiothreitol (DTT), 10\% (v/v) glycerol, and either $500 \mathrm{ng}$ salmon sperm DNA or $1 \mu \mathrm{g}$ polydIdC. In competition experiments, reactions were incubated for $10 \mathrm{~min}$ at room temperature with 100-fold molar excess unlabeled competitor probes prior to the addition of the radio-labeled probe.

\section{Ion exchange chromatography}

L $\beta$ T2 cells $\left(3 \times 10^{9}\right)$ were harvested for preparation of nuclear protein extracts using the protocol in Yaneva \& Tempst (2006) with some modifications. In brief, L $\beta$ T2 cells were collected and centrifuged at $800 \mathrm{~g}$ for $10 \mathrm{~min}$ at $4{ }^{\circ} \mathrm{C}$. The pellet was 
washed twice with $5 \mathrm{ml}$ cold $\mathrm{PBS}$, then resuspended in buffer A (10mM Tris- $\mathrm{HCl}, \mathrm{pH} 8,10 \mathrm{mM} \mathrm{KCl}, 0 \cdot 1 \mathrm{mM}$ EDTA, $0 \cdot 1 \mathrm{mM}$ EGTA, $1 \mathrm{mM}$ DTT, $0.5 \mathrm{mM}$ PMSF, $1 \mu \mathrm{g} / \mathrm{ml}$ aprotonin, $1 \mu \mathrm{g} / \mathrm{ml}$ pepstatin $\mathrm{A}$, and $0.2 \mathrm{mM}$ sodium vanadate), and transferred to a Dounce homogenizer. Cells were homogenized with 15 strokes of the pestle and incubated for $15 \mathrm{~min}$ on ice. Lysates were centrifuged at $3000 \mathrm{~g}$ for $15 \mathrm{~min}$ at $4{ }^{\circ} \mathrm{C}$, supernatant aspirated, and the pellet resuspended in minimal volume of low-salt extraction buffer $(20 \mathrm{mM}$ Tris- $\mathrm{HCl}, \mathrm{pH} 7 \cdot 5,20 \mathrm{mM} \mathrm{KCl}, 1.5 \mathrm{mM}$ $\mathrm{MgCl}_{2}, 0.2 \mathrm{mM}$ EDTA, and 25\% (v/v) glycerol). Lysates were homogenized with 15 more strokes of the pestle, then transferred to a small beaker with a magnetic stir bar. The solution was gently stirred at $4{ }^{\circ} \mathrm{C}$, while 0.5 volumes of high-salt extraction buffer $(20 \mathrm{mM}$ Tris- $\mathrm{HCl}, \mathrm{pH} 7 \cdot 5,1 \cdot 2 \mathrm{M}$ $\mathrm{KCl}, 1.5 \mathrm{mM} \mathrm{MgCl}_{2}, 0.2 \mathrm{mM}$ EDTA, and 25\% glycerol $(\mathrm{v} / \mathrm{v}))$ were added drop wise. The solution was stirred at $4{ }^{\circ} \mathrm{C}$ for an additional $30 \mathrm{~min}$, then transferred to $1.5 \mathrm{ml}$ tubes and centrifuged at $15000 \mathrm{~g}$ for $30 \mathrm{~min}$ at $4{ }^{\circ} \mathrm{C}$. Supernatants were collected and dialyzed overnight in 50 volumes of low-salt buffer D (20 mM HEPES-KOH pH 7.9, 0.2 mM EDTA, $10 \%$ glycerol (v/v), $0 \cdot 01 \%$ Nonidet-P40 (v/v), and $0 \cdot 075 \mathrm{M}$ $\mathrm{NaCl}$ ) in preparation for ion exchange chromatography. A HiTrap SP Sepharose FF (GE Healthcare) column was used to fractionate protein lysates. Proteins were eluted with a linear gradient of $0 \cdot 075-0.85 \mathrm{M} \mathrm{NaCl}$ in buffer $\mathrm{D}$, over 20 column volumes, at a flow rate of $0.4 \mathrm{ml} / \mathrm{min}$. Fourteen microliters of alternating fractions were analyzed for binding activity by gel shift using the $-106 /-77$ probe. Active fractions were pooled and concentrated using Amicon Ultra centrifuge tubes (Millipore).

\section{Chromatin immunoprecipitation}

Chromatin immunoprecipitation (ChIP) was carried out using the ChIP-IT Express kit (Active Motif, Carlsbad, CA, USA) according to the manufacturer's instructions. L $\beta$ T2 cells were grown to $70-80 \%$ confluence in $10 \mathrm{~cm}$ plates, and either untreated or treated with $25 \mathrm{ng} / \mathrm{ml}$ activin A for $1 \mathrm{~h}$. The cells were fixed using $10 \mathrm{ml}$ of fixation solution per plate $(0.27 \mathrm{ml}$ of $37 \%$ formaldehyde in $10 \mathrm{ml}$ of cell culture medium), and incubated for $10 \mathrm{~min}$ on a shaker at room temperature. The cells were washed with $10 \mathrm{ml}$ cold $1 \times$ PBS followed by $10 \mathrm{ml}$ of glycine stop-fix solution. The cells were then scraped in $1.2 \mathrm{ml}$ of cell scraping solution and collected in $15 \mathrm{ml}$ conical tubes on ice. Cells were centrifuged for $10 \mathrm{~min}$ at 2500 r.p.m. at $4{ }^{\circ} \mathrm{C}$. Supernatants were discarded and pellets were resuspended in $1 \mathrm{ml}$ cold lysis buffer, followed by incubation on ice for $30 \mathrm{~min}$. The cells were transferred to a Dounce homogenizer on ice, and homogenized with 10 strokes. Lysates were transferred to $1.5 \mathrm{ml}$ microcentrifuge tubes and centrifuged at 3500 r.p.m. for $10 \mathrm{~min}$ at $4{ }^{\circ} \mathrm{C}$. Supernatants were discarded, pellets resuspended in $200 \mu \mathrm{l}$ of digestion buffer and incubated at $37^{\circ} \mathrm{C}$ for $5 \mathrm{~min}$. Ten microliters of enzymatic shearing cocktail were added to each pellet, and samples were vortexed followed by incubation for $15 \mathrm{~min}$ at $37^{\circ} \mathrm{C}$. The reaction was stopped by adding $4 \mu \mathrm{l}$ of ice-cold $0.5 \mathrm{M}$ EDTA, and chilling on ice for $10 \mathrm{~min}$. Samples were centrifuged at 15000 r.p.m. at $4{ }^{\circ} \mathrm{C}$ for $10 \mathrm{~min}$. Supernatants (containing the sheared chromatin) were collected for immunoprecipitation.

Ten microliters of the chromatin from each plate were put aside as 'input DNA'. ChIP reactions were set up as follows: $25 \mu \mathrm{l}$ protein $\mathrm{G}$ magnetic beads, $10 \mu \mathrm{l}$ ChIP buffer $1,25 \mu \mathrm{l}$ sheared chromatin, $1 \mu \mathrm{l}$ protease inhibitor cocktail, and $3 \mu \mathrm{g}$ SMAD2 (Zymed, Cat. \# 51-1300) or rabbit IgG (Millipore, 12-370) in a final volume of $100 \mu \mathrm{l}$. Reactions were incubated overnight at $4{ }^{\circ} \mathrm{C}$ on the rotator. Magnetic beads were collected on magnets, and supernatants discarded. The beads were washed once with $800 \mu \mathrm{l} \mathrm{ChIP} \mathrm{buffer} 1$, and twice with $800 \mu \mathrm{l}$ ChIP buffer 2 . The final wash was removed, and the beads were resuspended in $50 \mu \mathrm{l}$ elution buffer AM2. Beads were incubated at room temperature for $15 \mathrm{~min}$ while flicking the tubes to mix. Fifty microliters of reverse crosslinking buffer were added and tubes were placed on a magnetic stand. Supernatants (containing chromatin) were transferred to $0.2 \mathrm{ml}$ PCR tubes. 'Input DNA' samples were mixed with $88 \mu \mathrm{l} \mathrm{ChIP} \mathrm{buffer} 2$, and $2 \mu \mathrm{l}$ of $5 \mathrm{M} \mathrm{NaCl}$ (final volume $100 \mu \mathrm{l}$ ). ChIP and 'Input DNA' samples were incubated at $95{ }^{\circ} \mathrm{C}$ for $15 \mathrm{~min}$. Samples were cooled to room temperature, and $2 \mu \mathrm{l}$ proteinase $\mathrm{K}(0.5 \mu \mathrm{g} / \mu \mathrm{l})$ was added. Samples were incubated at $37^{\circ} \mathrm{C}$ for $1 \mathrm{~h}$. Tubes were cooled to room temperature and $2 \mu \mathrm{l}$ proteinase $\mathrm{K}$ stop solution was added. Five microliters of each template were analyzed using the GoTaq PCR Core system (Promega), in a final volume of $25 \mu \mathrm{l}$. Fifteen microliters of each reaction were subject to electrophoresis on a $2 \%(\mathrm{w} / \mathrm{v})$ agarose gel, using the $-253 /-232$ sense and $-13 /+9$ primers in Table 1.

\section{DNA-affinity pull-down}

Fifty microliters of M-280 streptavidin-coated Dynabeads (Invitrogen) were washed twice in $500 \mu \mathrm{l}$ of $2 \times \mathrm{B} \& \mathrm{~W}$ buffer (10 mM Tris- $\mathrm{HCl} \mathrm{pH7 \cdot 5,} 1 \mathrm{mM}$ EDTA, and $2 \mathrm{M} \mathrm{NaCl}$ ). Five hundred microliters of $1 \times \mathrm{B} \& \mathrm{~W}$ buffer were added, along with $20 \mu \mathrm{l}$ of $10 \mu \mathrm{M}$ double-stranded biotinylated $-106 /-77$ probe. Beads were incubated with probe for $30 \mathrm{~min}$ at room temperature with gentle mixing. Beads were then washed thrice in $500 \mu \mathrm{l}$ of $1 \times \mathrm{B} \& \mathrm{~W}$ buffer, and once in $500 \mu \mathrm{l}$ of $1 \times$ binding buffer $(20 \mathrm{mM}$ Tris- $\mathrm{HCl}, \mathrm{pH} 7 \cdot 5$, $1 \mathrm{mM}$ EDTA, $1 \mathrm{mM}$ DTT, 5\% glycerol (v/v), $100 \mathrm{mM}$ $\mathrm{NaCl}, 0 \cdot 15 \%$ Triton X-100 (v/v), and $4 \mathrm{mM} \mathrm{MgCl}_{2}$ ). Beads were incubated in $500 \mu \mathrm{l}$ of $1 \times$ binding buffer containing $1 \%$ BSA (w/v) for $30 \mathrm{~min}$ at room temperature with gentle mixing. Beads were collected on a magnet and resuspended in $50 \mu \mathrm{l}$ of $1 \times$ binding buffer. Ninety microliters of $5 \times$ binding buffer, $10 \mu \mathrm{l}$ of $1 \mu \mathrm{g} / \mu \mathrm{l}$ poly $\mathrm{dIdC}$, and $100 \mu \mathrm{g}$ L $\beta \mathrm{T} 2$ wholecell lysates (in $100 \mu \mathrm{l}$ lysis buffer: $300 \mathrm{mM} \mathrm{NaCl}, 20 \mathrm{mM}$ Tris-HCl, pH7·5, 1\% Triton X-100 (v/v), 1 mM PMSF, $20 \mu \mathrm{g} / \mathrm{ml}$ leupeptin, and $20 \mu \mathrm{g} / \mathrm{ml}$ aprotonin) in a total volume of $500 \mu \mathrm{l}$ were added. The beads were incubated at 
$4{ }^{\circ} \mathrm{C}$ with gentle mixing overnight and then washed five times in $1 \times$ binding buffer, collected in $25 \mu$ l of loading buffer, and boiled at $100{ }^{\circ} \mathrm{C}$ for SDS-PAGE (10\% Bis-Tris). The proteins were transferred to nitrocellulose membranes. Western blots were performed as described previously (Bernard 2004).

\section{Southwestern blots}

Protein fractions from ion exchange chromatography that showed binding activity in gel shifts were denatured and run on SDS-PAGE (12\% Bis-Tris) under reducing conditions, followed by transfer onto nitrocellulose membranes. Membranes were incubated in renaturing buffer $(20 \mathrm{mM}$ HEPES pH7.9, $50 \mathrm{mM} \mathrm{KCl,} 1 \mathrm{mM}$ DTT, 10\% glycerol (v/v), and $0 \cdot 1 \%$ Nonidet P-40 (v/v)) for $45 \mathrm{~min}$ at room temperature on a rocking platform. The membrane was then incubated for $3 \mathrm{~h}$ at room temperature in blocking buffer $(10 \mathrm{ml}$ of renaturing buffer containing $5 \%(\mathrm{w} / \mathrm{v})$ nonfat milk). The blots were then cut into sections and incubated in the appropriate hybridization mix. Hybridization mixes were prepared by adding $10^{6}$ c.p.m. $/ \mathrm{ml}$ of $-106 /-77$ radiolabeled probe alone or with 100-fold molar excess of unlabeled homologous or heterologous competitor probes (Table 1) to renaturing buffer containing $0 \cdot 5 \%$ nonfat milk (w/v) and $5 \mu \mathrm{g} / \mathrm{ml}$ of polydIdC or $5 \mu \mathrm{g} / \mathrm{ml}$ ssDNA. Blots were hybridized for $1 \mathrm{~h}$ at room temperature, followed by three washes in binding buffer, $20 \mathrm{~min}$ per wash. Membranes were blotted dry with Whatman paper, wrapped in plastic wrap, and exposed on X-ray film at $-80^{\circ} \mathrm{C}$ with intensifying screens.

\section{Primary granulosa cell culture}

Cluster of differentiation-1 mice (Mus musculus) were killed on postnatal days 22-23, and ovaries from 10 to 20 animals were pooled for granulosa cell collection. Granulosa cells were collected through follicle puncture as previously described with slight modification (Kipp et al. 2007). Oocytes were filtered out with a $40 \mu \mathrm{m}$ cell strainer (BD Falcon, Bedford, MA, USA). Granulosa cells were cultured in a humidified incubator at $37^{\circ} \mathrm{C} / 5 \% \mathrm{CO}_{2}$ in a DMEM/F12 medium (Invitrogen) supplemented with $2 \mu \mathrm{g} / \mathrm{ml}$ insulin, $5 \mathrm{nM}$ sodium selenite, $5 \mu \mathrm{g} / \mathrm{ml}$ transferrin, $0.04 \mu \mathrm{g} / \mathrm{ml}$ hydrocortisone, $50 \mu \mathrm{g} / \mathrm{ml}$ sodium pyruvate, and 10\% FBS (v/v) (Invitrogen) for 3 days before transfection. All animals were handled in accordance with institutional and federal guidelines.

\section{Primary granulosa cell transfection and luciferase assays}

Transient transfections were performed with 450 ng of pGL3basic or the indicated murine Hsd17b1 constructs plus $100 \mathrm{ng}$ of pcDNA3.0 or ALK4-T206D per well of a 24-well culture plate using cationic liposomes in $500 \mu \mathrm{l}$ Opti-MEM (Invitrogen; Burkart et al. 2005). After $6 \mathrm{~h}$ of transfection, cells were allowed to recover in the medium without serum for $16-20 \mathrm{~h}$. At the end of recovery, cells were washed with PBS and lysed on ice for $20 \mathrm{~min}$. The lysis buffer contained $25 \mathrm{mM}$ HEPES, pH 7·8, $15 \mathrm{mM} \mathrm{MgSO}_{4}, 4 \mathrm{mM}$ EGTA, $1 \mathrm{mM}$ DTT, and $0 \cdot 1 \%$ Triton X-100 (v/v). Cell lysates $(100 \mu \mathrm{l})$ were then added to $400 \mu \mathrm{l}$ of reaction buffer (25 mM HEPES (pH 7.8), 15 mM $\mathrm{MgSO}_{4}, 4 \mathrm{mM}$ EGTA, $2.5 \mathrm{mM}$ ATP, $1 \mathrm{mM}$ DTT, $1 \mu \mathrm{g} / \mathrm{ml} \mathrm{BSA}$, and $100 \mu \mathrm{l}$ of $1 \mathrm{mM}$ luciferin (sodium salt) (Analytical Bioluminescence, San Diego, CA, USA)) and emitted luminescence measured using a 2010 luminometer (Analytical Bioluminescence) for $10 \mathrm{~s}$. Relative light units were normalized for total protein content measured with the Bio-Rad protein assay reagent, and data presented as fold change from the promoter-less vector in the presence of pcDNA3. 0 .
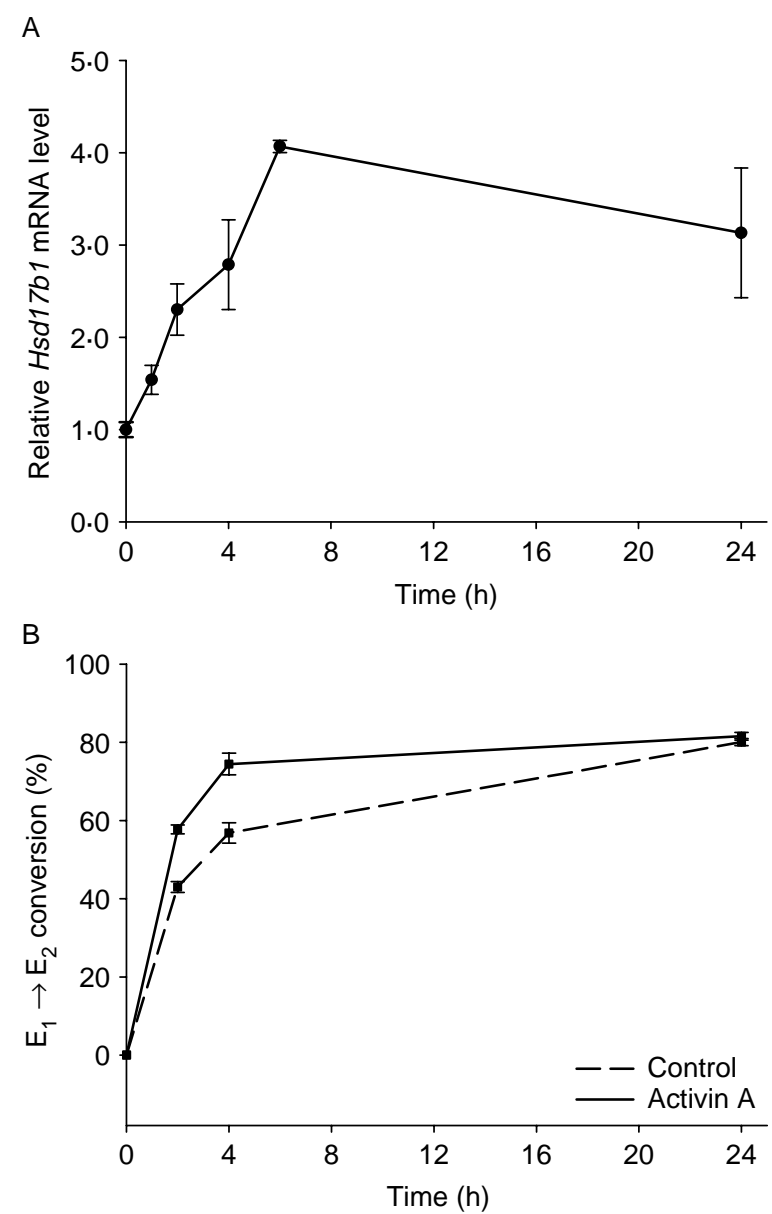

Figure 1 (A) L $\beta$ T2 cells were treated with $25 \mathrm{ng} / \mathrm{ml}$ of activin A for $0,1,2,4,6$, and $24 \mathrm{~h}$. Hsd1 7 b1 mRNA levels were measured by qRT-PCR. Data are the mean relative mRNA levels ( \pm s.D.) with the control condition (no treatment) set to 1 . The analysis was repeated twice with comparable results. (B) L $\beta T 2$ cells were incubated in control or activin A-containing media overnight $(25 \mathrm{ng} / \mathrm{ml})$. The percent conversion of estrone $\left(E_{1}\right)$ to estradiol $\left(E_{2}\right)$ was measured by TLC as described in the Materials and Methods. All treatments were performed in triplicate. 


\section{Results}

Activin A stimulates an increase in Hsd17b1 $\mathrm{mRNA}$ and $17 \beta$ HSD1 enzymatic activity

Total RNA from L $\beta$ T2 cells cultured in serum-free DMEM for $24 \mathrm{~h}$ in the presence or absence of $25 \mathrm{ng} / \mathrm{ml}$ activin A was subjected to analysis with Affymetrix 430 gene arrays. Based on the results of duplicate samples, the gene for the

A
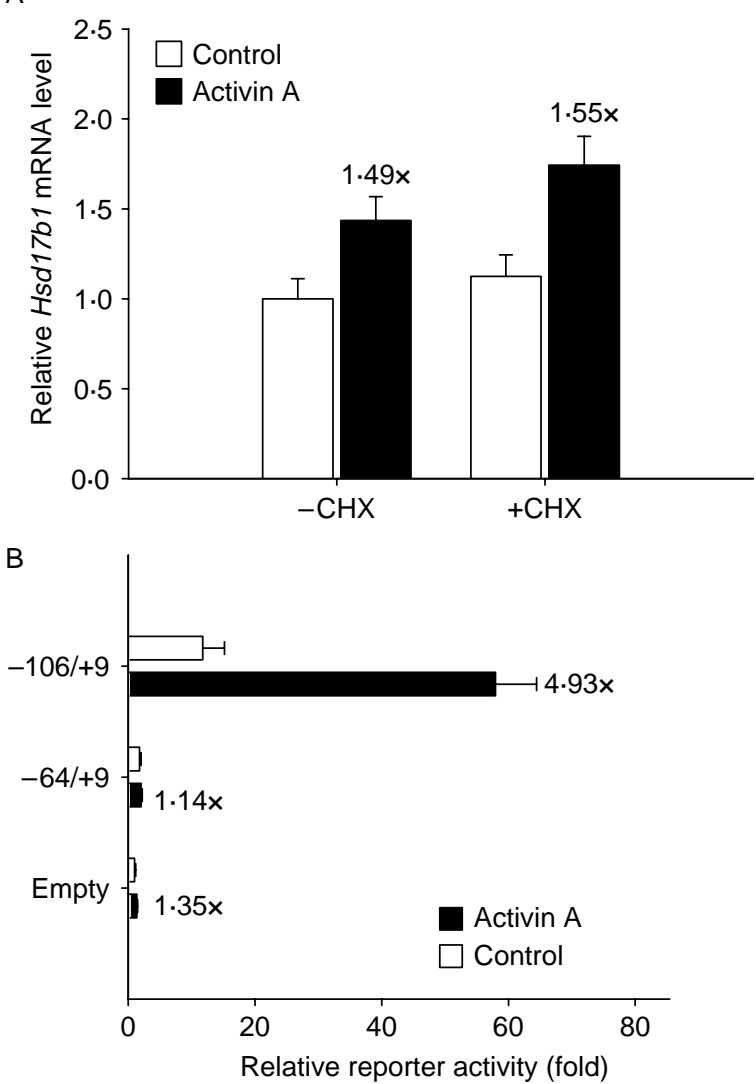

C

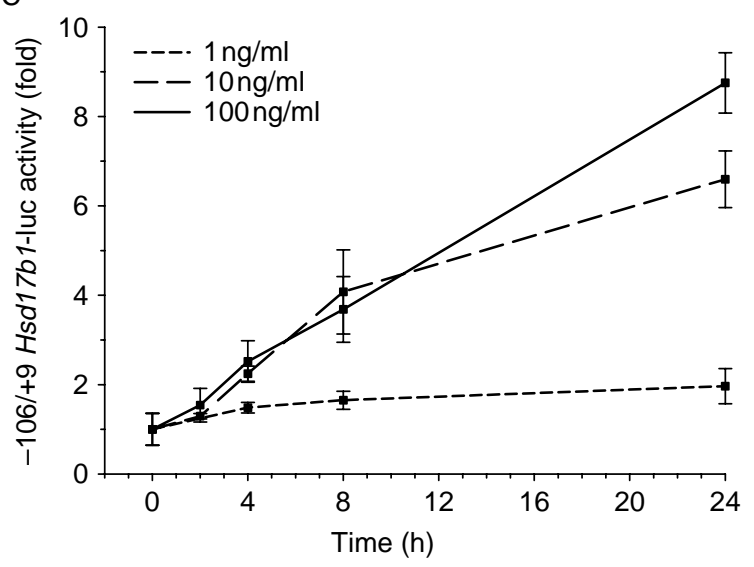

steroidogenic enzyme 17 $\beta$-HSD1 (Hsd17b1) appeared to be upregulated to the greatest extent (data not shown). Quantitative RT-PCR analysis of L $\beta$ T2 cells treated with activin A confirmed a rapid and sustained induction of Hsd17b1 mRNA (Fig. 1A). Hsd17b1 mRNA expression in adult male and female mouse pituitaries was verified by RT-PCR (data not shown).

To determine whether the increased mRNA was associated with increased protein levels, we measured 17 $\beta$-HSD1 enzymatic activity in L $\beta$ T2 cells. After overnight incubation with $1 \mathrm{nM}$ activin A, cells were incubated with $5 \mathrm{nM}$ tritiated $\mathrm{E}_{1}$ and conversion to $\mathrm{E}_{2}$ measured by thin-layer chromatography after 2, 4, or $24 \mathrm{~h}$. By $24 \mathrm{~h}$, L $\beta \mathrm{T} 2$ cells in both conditions had converted $80 \%$ of $\mathrm{E}_{1}$ to $\mathrm{E}_{2}$. At the earlier time points, however, activin A shifted the curve to the left relative to control, indicative of enhanced $17 \beta-$ HSD1 enzymatic activity (Fig. 1B).

Activin A directly stimulates Hsd17b1 transcription through a proximal promoter region

Activin A induction of Hsd17b1 mRNA levels was rapid, with increases observed within $1 \mathrm{~h}$ (Fig. 1A). This suggested that $H s d 17 b 1$ might be an immediate-early response gene. To test this idea, we pretreated the cells with the translation inhibitor, cycloheximide, for $15 \mathrm{~min}$ prior to activin A treatment for $1 \mathrm{~h}$. Cycloheximide affected neither basal nor activin A-stimulated Hsd17b1 mRNA levels (Fig. 2A), indicating that protein synthesis was not required for the activin A effect. To further confirm that activin A regulates $H s d 71 b 1$ at the transcriptional level, we ligated -1019 to +9 of the murine $H s d 71 b 15^{\prime}$ flanking region upstream of a luciferase reporter gene. When transfected into L $\beta$ T2 cells, the reporter conferred significant basal and activin A-stimulated activity relative to the promoter-less parental vector (data not shown). $5^{\prime}$ deletions to $-517,-253$, or -106 did not significantly alter reporter activity; however, truncating the reporter to -64 abolished both the basal and activin A-dependent activity (Fig. $2 \mathrm{~B}$ and data not shown).

Figure 2 (A) L $\beta T 2$ cells were treated with $5 \mu \mathrm{g} / \mathrm{ml}$ cycloheximide (CHX) $15 \mathrm{~min}$ prior to $1 \mathrm{~h}$ treatment with $25 \mathrm{ng} / \mathrm{ml}$ activin A. Hsd17b1 mRNA levels were measured by qRT-PCR. Results were normalized to the untreated samples ( $-\mathrm{CHX}$, control). Data are means ( \pm s.E.M.) of triplicate samples. The analysis was repeated twice with comparable results. (B) L $\beta T 2$ cells were transfected with $450 \mathrm{ng} /$ well of the indicated murine $\mathrm{Hsd} 17 \mathrm{~b} 1$-luc reporters, followed by $24 \mathrm{~h}$ treatment with $25 \mathrm{ng} / \mathrm{ml}$ activin A. Data show luciferase activity, normalized relative to the empty pGL3-Basic vector. The fold increase induced by activin $A$ is shown for each reporter. The data are means (+S.D.) of triplicate samples. The experiment was repeated thrice with comparable results. (C) L $\beta T 2$ cells transfected with $-106 /+9 H s d 17 b 1$-luc were treated for the indicated time periods with 1, 10, or $100 \mathrm{ng} / \mathrm{ml}$ activin A. Relative luciferase activity is shown relative to untreated $(0 \mathrm{~h})$ cells. Data are means ( \pm s.D.) of duplicate samples, and the experiment was repeated thrice with comparable results. 


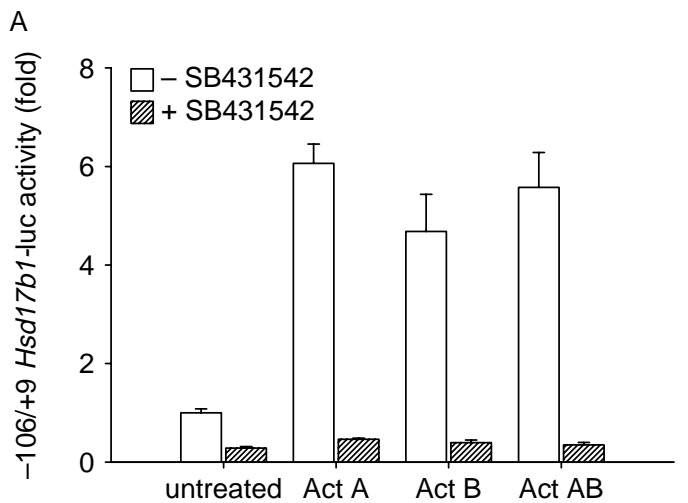

B
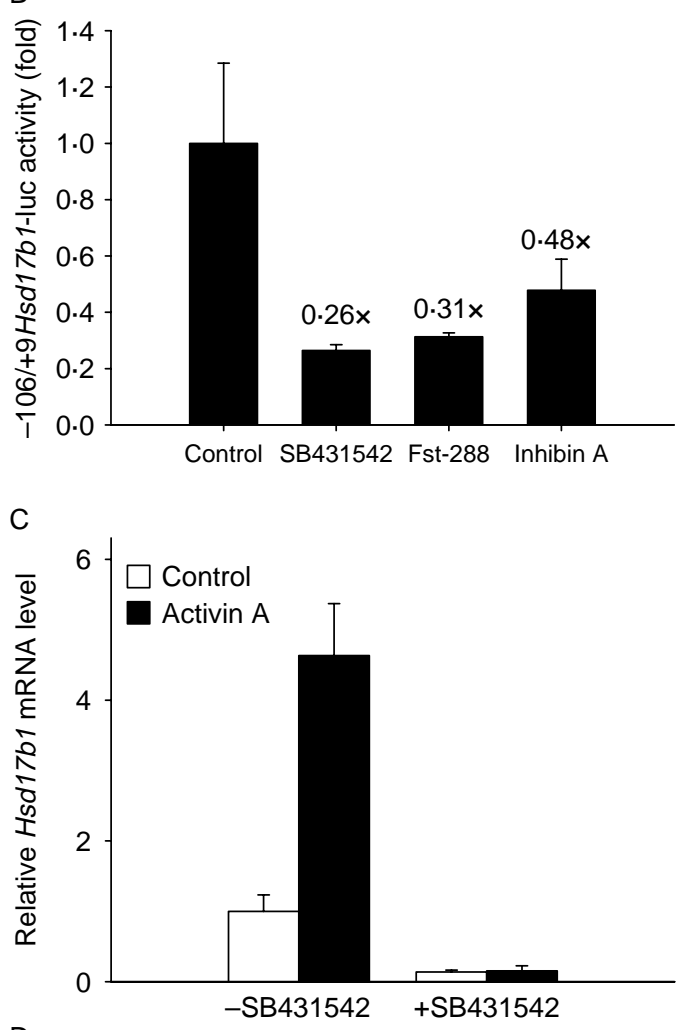

D

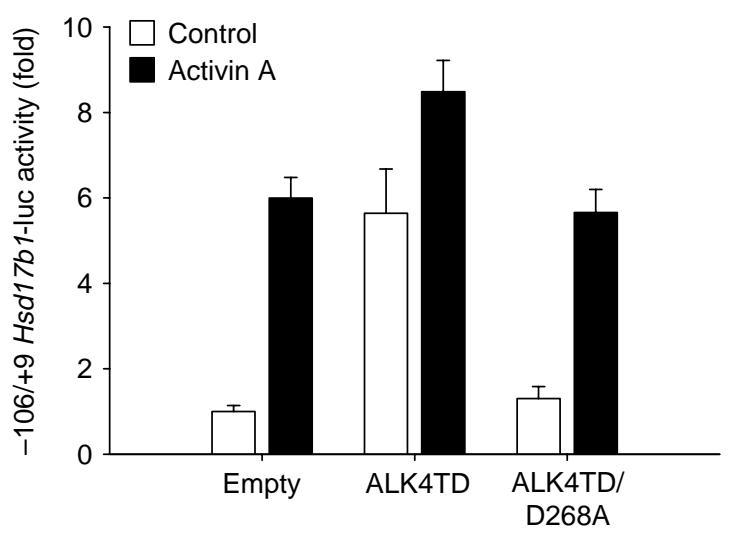

Therefore, in subsequent analyses, we used the minimally responsive $-106 /+9 H s d 17 b 1$-luc. This reporter was both time- and dose-dependently regulated by activin $\mathrm{A}$, with increased activity observed within 2 to $4 \mathrm{~h}$ at 10 and $100 \mathrm{ng} / \mathrm{ml}$ concentrations (Fig. 2C). Because reporter activity requires both transcription and translation of the luciferase gene, this timing was consistent with an immediate-early response as seen with the endogenous gene.

Activins signal through the type I receptor, ALK4, to stimulate Hsd17b1 transcription

In the canonical activin signaling pathway, activins bind to a type II receptor serine/threonine kinase (ACVR2A or ACVR2B), which then phosphorylates a type I receptor, (ALK4, also known as ACVR1B). Activated ALK4 then propagates intracellular signals, which are classically mediated by SMAD proteins. SB431542 is a selective and potent small molecule inhibitor of ALKs 4, 5, and 7 (Laping et al. 2002). Thirty-minute pretreatment with this compound abolished the $24 \mathrm{~h}$ effects of three forms of activin (activin A, B, or AB), and significantly reduced basal reporter activity (Fig. 3A). These data indicated that ALKs 4, 5, and/or 7 were required for exogenous ligand action, regardless of activin subtype. The effect on basal activity suggested that endogenous signaling via one or more of these receptors might contribute to the high 'basal'Hsd17b1 expression and $17 \beta-H S D 1$ enzymatic activity in these cells.

We previously showed that the Inhbb, but not Inhba subunit is expressed in L $\beta$ T2 cells (Lee et al. 2007). Homodimers of the INHBB protein form activin B. Activin B was implicated as the physiologically relevant activin in gonadotropes in vivo (Roberts et al. 1989, Corrigan et al. 1991, DePaolo et al. 1992). Therefore, the $70 \%$ decrease in basal reporter activity

Figure 3 (A) L $\beta$ T2 cells were transfected with $450 \mathrm{ng} /$ well of $-106 /+9$ Hsd17b1-luc reporter. The following day, cells were treated with $10 \mu \mathrm{M}$ SB431542 for 30 min followed by 24-h treatment with $25 \mathrm{ng} / \mathrm{ml}$ activin A, B, or AB. Data show the mean of triplicates (+S.D.), normalized relative to the untreated group. The experiment was repeated thrice with similar results each time. (B) Cells were transfected with 450 ng/well of -106/+9 Hsd17b1luc reporter. The next day, cells were treated with 10 MM SB431542, $100 \mathrm{ng} / \mathrm{ml}$ follistatin, or $100 \mathrm{ng} / \mathrm{ml}$ inhibin A for $24 \mathrm{~h}$. Treatments were performed in triplicate and data show the mean (+s.D.) reporter activity relative to control set to 1 . The experiment was repeated thrice. (C) Cells were treated with $10 \mu \mathrm{M}$ SB431542 for $30 \mathrm{~min}$ followed by 24-h treatment with $25 \mathrm{ng} / \mathrm{ml}$ activin A. Hsd17b1 mRNA levels were measured by qRT-PCR. Data show means of triplicate samples (+s.D.), normalized relative to the untreated group. The experiment was repeated twice with similar results. (D) L $\beta T 2$ cells were transfected with $450 \mathrm{ng} /$ well of -106/+9 Hsd17b1-luc reporter and 100 ng/well ALK4-T206D or ALK4-T206D/D268A expression vectors. The following day, cells were treated for $24 \mathrm{~h}$ with $25 \mathrm{ng} / \mathrm{ml}$ of activin A. Data show the mean of triplicate samples (+S.D.), normalized to the control pcDNA3 $\cdot 0$ vector in the absence of ligand. The experiment was repeated thrice. 
with SB431542 treatment might reflect the inhibition of endogenous activin $\mathrm{B}$ signaling. We observed that exogenous activin $\mathrm{B}$ was as effective as activin $\mathrm{A}$ in stimulating reporter activity and was similarly inhibited by SB431542 (Fig. 3A). Therefore, to assess a potential role for endogenous activin $\mathrm{B}$ in basal Hsd17b1 expression, the cells were transfected with the minimal reporter and treated overnight with SB431542, follistatin-288 (Fst-288), or inhibin A. Fst-288 binds and bioneutralizes activins, whereas inhibins are competitive antagonists of activin type II receptors (Harrison et al. 2005). All three inhibitors suppressed basal activity to $30-50 \%$ of the control (Fig. 3B). We then measured endogenous Hsd17b1 mRNA levels in the presence of SB431542. As with the reporter, the inhibitor both strongly suppressed basal gene expression and completely blocked the $24 \mathrm{~h}$ effect of activin A (Fig. 3C).

Though recent data indicated that activin $\mathrm{AB}$ and $\mathrm{B}$ signal via ALK4 and/or 7, activin A signals through ALK4 alone (Tsuchida et al. 2004, Bernard et al. 2006). Activin signaling via ALK5 has not been reported. Therefore, the effects of SB431542, at least in the case of exogenous activin A, were most likely attributable to antagonism of ALK4 signaling. To confirm that ALK4 was sufficient for the induction of Hsd17b1 reporter activity, we transfected the cells with a constitutively active form of ALK4 (T206D (Attisano et al. 1996)), which can signal in the absence of ligands. The receptor stimulated $H s d 17 b 1$ reporter activity to the same extent as exogenous activin A (Fig. 3D). Cells transfected with ALK4-T206D and then treated with activin A showed the highest reporter activity, though the effect was less than additive. Together, the data suggested that ALK4 was sufficient and, perhaps, necessary for endogenous and exogenous activin-mediated $H s d 17 b 1$ transcription.

\section{Activins signal through SMAD2, but not SMAD3, to stimulate Hsd $17 b 1$ transcription}

ALK4 propagates intracellular signals via phosphorylation of effector substrates. Although the receptor-regulated SMADs, SMAD2 and SMAD3, are the most thoroughly described effectors, ALKs can also generate SMAD-independent signals in cell-specific fashion (Derynck \& Zhang 2003). We therefore examined whether activin A and ALK4 use SMAD proteins to signal to the Hsd17b1 promoter. First, we introduced a point mutation, D268A, into the kinase domain of the constitutively active ALK4-T206D. The comparable mutation in ALK5 (D226A) inhibited the ability of the receptor to stimulate SMAD2 phosphorylation (Itoh et al. 2003). Whereas ALK4-T206D strongly stimulated the SMAD-responsive reporter, CAGA 12 -luc, ALK4-T206D/ D268A had no effect (data not shown). Therefore, the D268A mutation successfully impaired SMAD-dependent signaling by ALK4-T206D in L $\beta$ T2 cells. ALK4-T206D/D268A also failed to stimulate $H s d 17 b 1$ reporter activity, suggesting that ALK4 might signal, at least in part, through SMADs to regulate transcription (Fig. 3D).
To more definitively demonstrate the roles for SMADs, we co-transfected SMAD2 or SMAD3 expression vectors with the Hsd17b1 reporter followed by overnight activin A treatment. SMAD over-expression can both mimic and potentiate the effects of ligand, when the response is SMAD dependent. SMAD2 increased basal reporter activity twofold and potentiated the activin A response (Fig. 4A). SMAD3 over-expression had no effect. Next, we knocked down the expression of SMAD2 or SMAD3 using previously validated short-hairpin (sh) RNA-expressing plasmids (Bernard 2004). The SMAD2 shRNA decreased activin A-stimulated reporter activity (Fig. 4B) by about $40 \%$. The magnitude of the effect was the same regardless of the amount of shRNA vector transfected. There was no notable effect on basal reporter activity. The SMAD3 shRNA did not inhibit basal or activin A-regulated reporter activity (Fig. 4C).

Because SMAD2 does not bind DNA directly (Dennler et al. 1999, Yagi et al. 1999), but can bind indirectly through partnering with SMAD4, we asked whether the latter might play a role in $H s d 17 b 1$ transcription. L $\beta$ T2 cells were transfected with the $-106 /+9$ reporter alone or with one of three siRNAs: one control and two directed against SMAD4. Relative to cells without siRNA, transfection of SMAD4 siRNA \#2 significantly inhibited basal reporter activity (Fig. 4D). The control siRNA and SMAD4 siRNA \#1 had no effect. Importantly, we observed that SMAD4 siRNA $\# 2$, but not \#1, inhibited SMAD4 expression in these cells (Wang, unpublished; data not shown). When controlling for differences in basal activity, none of the siRNAs inhibited the fold activin A response. These data suggested that SMAD4 plays a role in basal reporter activity (which may depend on endogenous activin B signaling), but not in exogenous activin A-regulated activity.

SMADs 3 and 4 can regulate transcription by binding directly to DNA via low-affinity SMAD-binding elements (SBE), AGAC or GTCT. When we screened the activinresponsive -106 to -64 promoter region for candidate SBEs, we identified AGAC at $-90 /-87$. To assess the functional importance of this sequence, we introduced mutations into the first $2 \mathrm{bp}$ at $-90 /-89(\mathrm{AG} \rightarrow \mathrm{CT})$, which would be predicted to inhibit SMAD binding (Shi et al. 1998). When transfected into L $\beta$ T2 cells, the mutant promoter showed a complete loss of both basal and activin A-induced reporter activity (Fig. 4E).

To determine whether SMADs bind this element basally and/or in response to activin A treatment, we performed DNA-affinity pull-down coupled with western blots. A biotinylated double-stranded DNA probe, corresponding to $-106 /-77$ of the $H s d 17 b 1$ promoter, was incubated with lysates from control or activin A-treated $(1 \mathrm{~h})$ cells. Western blots of whole-cell extracts demonstrated both basal and activin A-stimulated SMAD2 phosphorylation (pSMAD2), with the signal enhanced in the latter (Fig. 4F, lanes 1 and 2). The DNA probe precipitated both pSMAD2 and a smaller protein, likely to be the SMAD2 splice variant, SMAD2$\Delta$ exon3 (Bernard 2004). Importantly, the latter can bind 
A

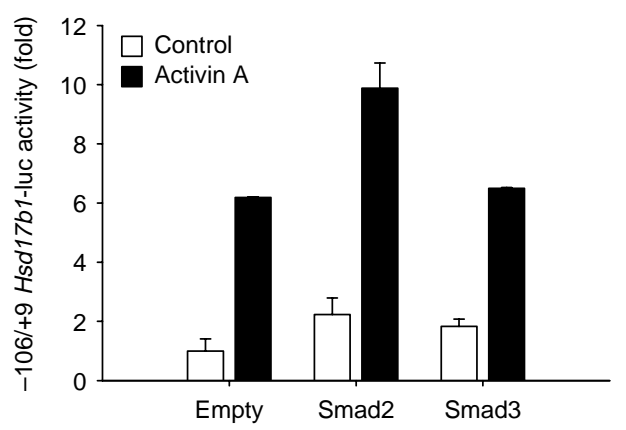

B

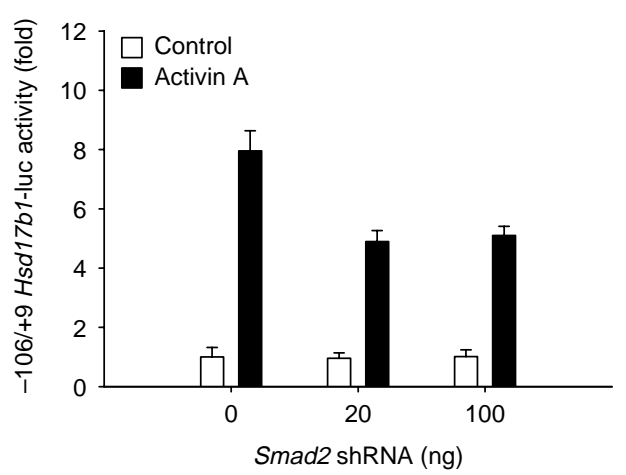

$\mathrm{E}$

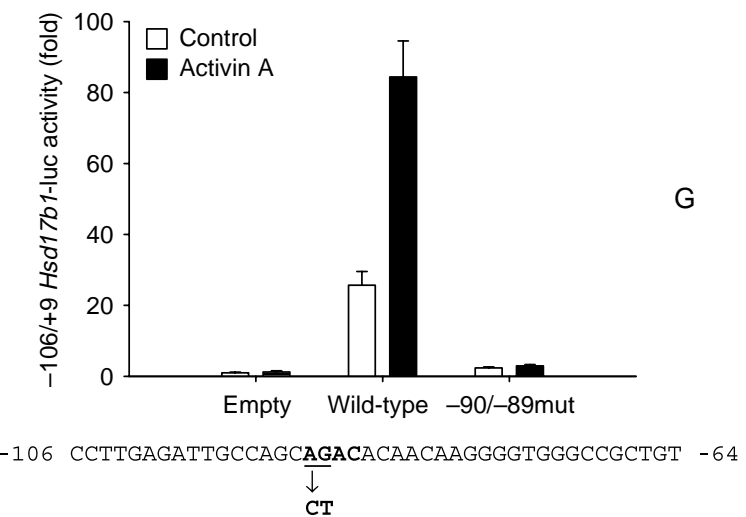

C

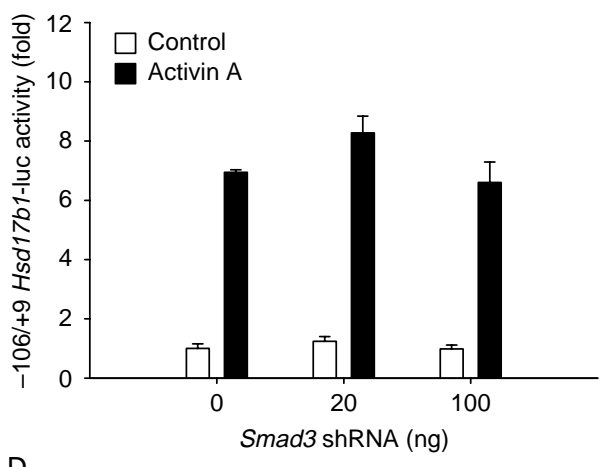

D

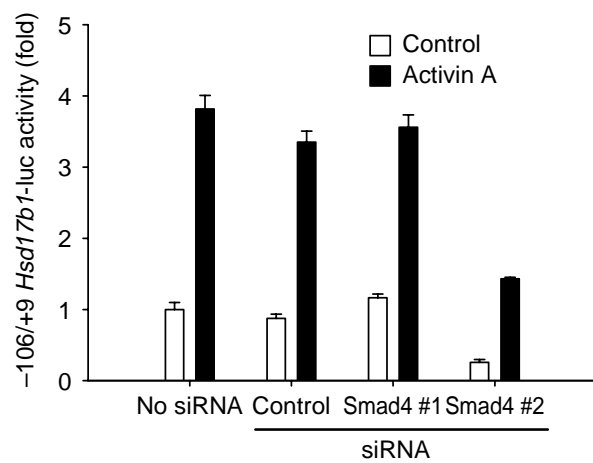

$\mathrm{F}$
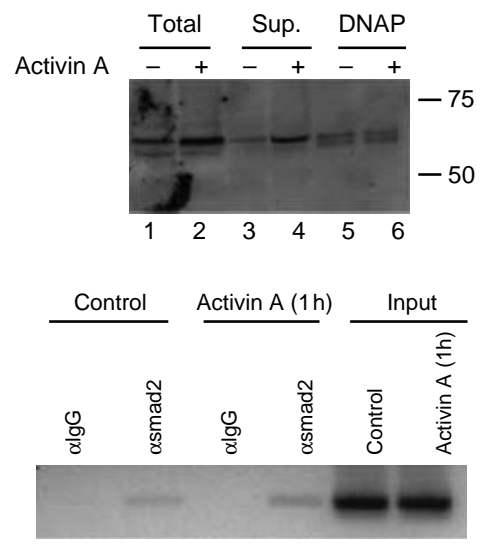

Figure 4 (A) L $\beta T 2$ cells were transfected with $450 \mathrm{ng} /$ well of $-106 /+9$ Hsd17b1-luc and $100 \mathrm{ng} /$ well of either pcDNA3·0, SMAD2, or SMAD3 expression vectors, followed by $24 \mathrm{~h}$ treatment with $25 \mathrm{ng} / \mathrm{ml}$ activin A. Data show means of duplicate samples (+ s.D.), normalized relative to the empty vector without ligand. The experiment was repeated four times. (B and C) Cells were transfected with $450 \mathrm{ng} / \mathrm{well}$ of $-106 /+9$ Hsd17b1-luc and 0, 20, or 100 ng/well of SMAD2 or 3 shRNA in pBS/U6 constructs. Empty pBS/U6 vector was used as control. The data are means of triplicates (+s.D.), normalized relative to the empty pBS/U6 vector without ligand. The experiments were repeated four times. (D) LBT2 cells were transfected with $450 \mathrm{ng} /$ well of $-106 /+9$ Hsd17b1-luc and $5 \mathrm{nM}$ of either control, or two different SMAD4 siRNAs, followed by $24-\mathrm{h}$ treatment with $25 \mathrm{ng} / \mathrm{ml}$ activin A. Data show means of triplicate samples (+s.E.M.), normalized to $-106 /+9$ Hsd17b1-luc basal activity in the absence of any siRNA. The experiment was repeated twice with comparable results. (E) Wild-type and -90/-89 mutant $-106 /+9$ Hsd17b1-luc reporters were transfected into L $\beta T 2$ cells followed by $24-\mathrm{h}$ treatment with $25 \mathrm{ng} / \mathrm{ml}$ activin A. Data show means of duplicates (+s.D.), normalized relative to pGL3-Basic (empty) vector. The experiment was repeated thrice. (F) L $\beta T 2$ cells were cultured for $1 \mathrm{~h}$ in the presence or absence of activin A. Protein lysates were subjected to DNA-affinity pull-down (DNAP) with a biotinylated $-106 /-77$ probe. Total (lanes 1 and 2), supernatant (Sup., lanes 3 and 4), and precipitated proteins (lanes 5 and 6 ) were subjected to western blot with a phospho-SMAD2 antibody. (G) Chromatin immunoprecipitation (ChIP) analysis of control or activin Atreated ( $1 \mathrm{~h}$ ) L $\beta$ T2 cells. Chromatin was precipitated with control IgG or SMAD2 antibody. DNA was amplified with primers flanking the SBE in the Hsd17b1 gene. 
DNA directly (Dennler et al. 1999, Yagi et al. 1999). The two proteins were pulled down in equal proportions (lanes 5 and $6)$, despite clear differences in their abundance as seen in whole-cell extracts (lanes 1 and 2) and as reported previously (Bernard 2004). The amount of pSMAD2 pulled down was not affected by activin A treatment. A probe containing the 2 bp mutation at $-90 /-89$ failed to precipitate pSMAD2 (data not shown). SMAD2 interaction with this part of the Hsd17b1 promoter in L $\beta$ T2 cells was confirmed by ChIP (Fig. 4G). Here, we detected a modest increase in the interaction following activin A treatment.

\section{Several nuclear proteins bind within the minimal Hsd17b1 promoter region}

The reporter data point to the promoter region between -106 and -64 as critical for both basal and activin-induced Hsd17b1 transcriptional activity in L $\beta$ T2 cells. SMADs are low-affinity DNA-binding proteins and typically bind with co-factors to mediate their effects on transcription. Therefore, to identify other critical cis-elements and their associated binding proteins, we performed gel shift analyses with two overlapping probes, $-106 /-77$ and $-86 /-57$, which encompassed the $-106 /-64$ interval. Both probes were radio-labeled and incubated with nuclear extracts from control and activin A-treated (4 h) L $\beta$ T2 cells. We performed the binding reactions under a variety of conditions and noted significant differences in binding activity when altering the nonspecific DNA competitor, polydIdC versus salmon sperm (ss) DNA (Fig. 5A, compare lanes 1-4 and 5-8; and data not shown). With the $-106 /-77$ probe and ssDNA, we noted one prominent complex (labeled $\mathrm{c}$ in Fig. 5A), which was competed by 100 -fold molar excess unlabeled homologous and $-86 /-57$ probes (lanes 3 and 4 ). These data suggested that complex $\mathrm{c}$ bound within the overlapping region between the two probes, $-86 /-77$. Indeed, we observed a complex with the same mobility when using the radio-labeled $-86 /-57$ probe, and this was competed by both cold $-106 /-77$ and $-86 /-57$ probes (data not shown). No other specific complexes binding to the $-86 /-57$ probe were observed, and activin A treatment did not significantly alter complex binding to either probe. With the $-106 /-77$ probe and polydIdC as nonspecific competitor, we failed to detect complex c, but now observed three new complexes (lane 5, labeled a, b, and ${ }^{\star}$ ). The fastest mobility complex $(\star)$ appeared to be non-specific as it was not displaced by cold homologous probe (lane 7). By contrast, both complexes a and $b$ were displaced by cold $-106 /-77$ (lane 7 ), but not $-86 /-57$ (lane 8), suggesting that the binding of both occurred specifically and within the unique $-106 /-87$ interval.

To determine the specific bases mediating binding of complexes a, b, and c, we prepared a series of competitor $-106 /-77$ probes, in which 3 bp mutations were systematically introduced from the $5^{\prime}$ to $3^{\prime}$ end (Fig. 5B). These mutant (Mut) probes were tested for their abilities to displace binding to the wild-type radio-labeled $-106 /-77$ probe in the presence of polydIdC (Fig. 5C, lanes 1-9; for complexes a/b) or ssDNA (Fig. 5C, lanes 10-15; for complex c). Mut1-6 spanned the interval unique to $-106 /-87$, which was predicted to bind complexes a and $\mathrm{b}$. Each of these mutant probes (lanes 3-8), with the exception of Mut3 (lane 5; bp $-100 /-98$, GAT $\rightarrow$ TCG), could displace complex binding as well as wild type (lane 2). These data suggested that bp $-100 /-98$ was important for complex a/b binding, though the mutant probe could still displace binding to some extent (compare lanes 1 and 5) and a radio-labeled Mut3 probe could still bind complexes $\mathrm{a} / \mathrm{b}$, though less well than wild type (data not shown). Mutants 7 to 10 spanned the interval common to both probes, where complex c was predicted to bind. Indeed, Mut8 (lane 13; bp $-85 /-83, \mathrm{CAA} \rightarrow \mathrm{ACC}$ ) and, to a lesser extent, Mut7 (lane 12; -88/-86, ACA $\rightarrow$ CAC) were impaired in their abilities to compete for binding to complex c relative to wild type (lane 11) or Mut9 and 10 (lanes 14 and 15). The putative SBE (boxed in Fig. 5B) mapped to $-90 /-87$, which was mutated in Mut6 and 7 . Mut6 did not affect complex $\mathrm{a} / \mathrm{b}$ binding. Mut7 only partially disrupted binding to complex $\mathrm{c}$ and did so less than Mut8, which did not affect any bases in the putative SBE. Therefore, it seemed unlikely that complexes $\mathrm{a}, \mathrm{b}$, or c contained SMAD proteins. Indeed, inclusion of antibodies against SMADs 2 or 4 did not alter complex binding (data not shown). The same antibodies were shown to supershift or displace their targets in previous analyses (Lamba et al. 2006).

We next examined whether the bp mediating complex a/b or c binding played roles in basal and/or activin A-regulated promoter activity. We introduced the $3 \mathrm{bp}$ mutation at $-100 /-98$ (Mut3) in the context of $-106 /+9$ Hsd17b1luc and observed a complete loss of reporter activity, akin to what was observed with the SBE mutation (Fig. 5D, compare with Fig. 4E). This suggested that the proteins in complexes $\mathrm{a} / \mathrm{b}$ might be necessary for $H s d 17 b 1$ promoter activity in gonadotropes. Neither Mut7 nor 8 completely inhibited complex $\mathrm{c}$ binding, suggesting that some combination of $\mathrm{bp}$ in these mutants might maximally mediate binding. We therefore introduced a novel mutation (bp $-87 /-85$, $\mathrm{CAC} \rightarrow \mathrm{GGG}$ ), which encompassed bp represented in both mutants. Interestingly, this mutation significantly reduced basal reporter activity without affecting the fold activin A response (Fig. 5D). Therefore, the protein(s) in complex c might be critical specifically for basal promoter activity.

\section{Characterization of proteins binding the proximal Hsd17b1 promoter}

We used the in silico transcription factor binding program PROMO (Messeguer et al. 2002, Farre et al. 2003) to predict the identity of proteins binding to the elements identified in Fig. 5. We examined specifically those proteins predicted to bind to the wild type, but not mutant sequences. In the case of Mut3 (bp -100/-98), we observed a loss of predicted $\mathrm{C} / \mathrm{EBP} \alpha$ binding. This protein was intriguing for a few 


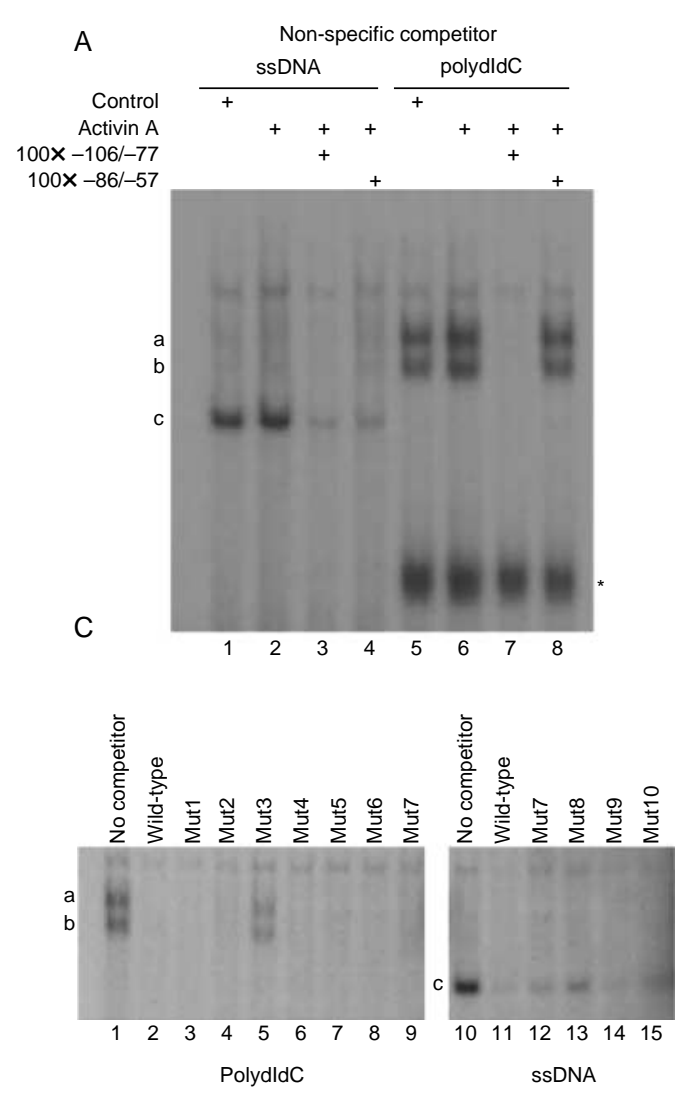

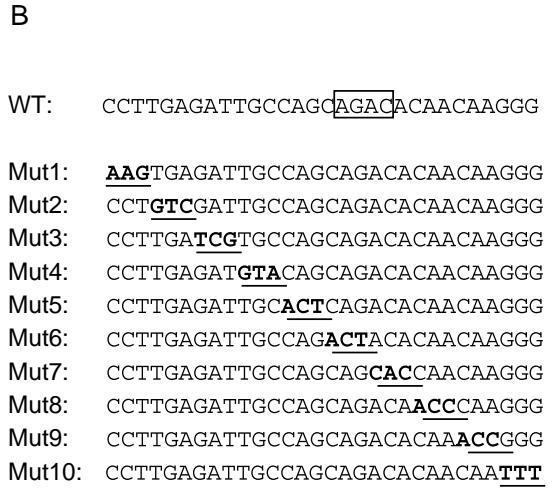

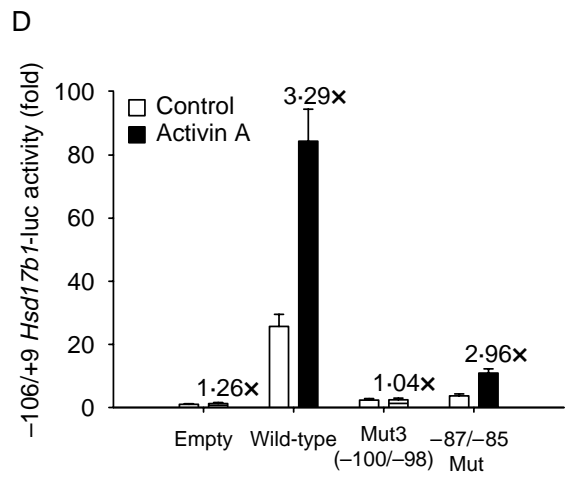

Figure 5 (A) A radio-labeled probe corresponding to $-106 /-77$ of the murine Hsd17b1 promoter was incubated with L $\beta T 2$ nuclear protein extracts in the presence of two nonspecific competitor DNAs, ssDNA (lanes 1-4) or polydldC (lanes 5-8). Binding specificity was determined by incubation with $100 \times$ molar excess of unlabeled homologous (lanes 3 and 7$)$ or heterologous ( $-86 /-57$ Hsd17b1, lanes 4 and 8) probes. Complexes formed under the two conditions are labeled on the left. (B) Sequences of mutagenized $-106 /-77$ probes (sense strand only) used as competitors in gel shifts with the radio-labeled wild-type (WT) $-106 /-77$ probe. (C) Competition assays in the presence of polydldC (left, lanes 1-9) or ssDNA (right, lanes 10-15). In all the cases, $100 \times$ molar excess of mutant probes was used to compete for binding to radiolabeled WT $-106 /-77$ Hsd17b1 probe. (D) L $\beta$ T2 cells were transfected with wild-type or the indicated mutant $-106 /+9$ Hsd17b1-luc reporters and then treated with $25 \mathrm{ng} / \mathrm{ml}$ activin A for $24 \mathrm{~h}$. Data reflect the means of duplicate samples (+s.D.), normalized relative to pGL3-Basic. The experiment was repeated thrice.

reasons. For example, we had already confirmed its expression in these cells (data not shown). Moreover, it is expressed in two major forms (42 and $30 \mathrm{kDa}$ ) through alternative translation initiation (Calkhoven et al. 1994), which could explain the complex a/b-binding pattern we observed. However, complex binding was not altered by the inclusion of a $\mathrm{C} / \mathrm{EBP} \alpha$ antibody in gel shift analyses (data not shown). In addition, we observed the same two complexes with nuclear extracts from $\alpha \mathrm{T} 3-1$ cells, which do not express $\mathrm{C} / \mathrm{EBP} \alpha$ (data not shown). In the case of complex $c$, the in silico analysis showed that a putative binding site for homeobox A3 (HOXA3) was disrupted in both probes Mut7 and 8; but this was not pursued further given the results of later experiments indicating the likely size of the protein in complex c (see below).

In the absence of viable candidates, we attempted to further characterize the binding proteins through experimental means. We fractionated L $\beta$ T2 cell nuclear extracts by cation exchange chromatography and examined the fractions for their binding activities in the established gel shift paradigm with the $-106 /-77$ probe using either polydIdC or ssDNA as nonspecific competitor, in order to isolate complexes $\mathrm{a} / \mathrm{b}$ and complex $\mathrm{c}$ (data not shown). We next collected proteins from fractions exhibiting high binding activity by SDS-PAGE and transferred them to nitrocellulose membranes for southwestern blot analyses with the radiolabeled $-106 /-77$ probe. Protein fractions containing complex a/b produced at least 12 hybridizing bands (Fig. 6A, labeled at right). Most were non-specific, as they were not competed when excess unlabeled homologous or heterologous probes were included in the binding reactions (bands $1,3,5-12$ ), or they were also observed in chromatographic fractions that had no binding activity in EMSAs (data not shown). We therefore focused on the two 
specific bands (labeled 2 and 4 in Fig. 6A, arrows) whose binding to the probe was diminished in the presence of cold homologous (lane 2) but not heterologous competitor probe (lane 3). Upon performing southwestern blot analysis with protein fractions containing complex c, we observed a specific complex of $\sim 35 \mathrm{kDa}$ (HOXA3 would be expected to migrate at $\sim 46 \mathrm{kDa}$, making it significantly larger than the protein we observed here) (Fig. 6B). We are currently attempting to purify all three proteins for identification by mass spectrometry.

\section{Regulation of Hsd17b1 transcription in immortalized and} primary cultured murine granulosa cells

Having discerned part of the mechanism through which activins regulate $H s d 17 b 1$ transcription in gonadotropes, we next asked whether this mechanism might be conserved across cell types. Previously, activin A was shown to stimulate Hsd17b1 mRNA levels in primary cultured rat granulosa cells (Ghersevich et al. 2000). Activin A also stimulated Hsd $17 b 1$ mRNA levels in primary cultured mouse granulosa cells from a microarray study (Kipp and Mayo, unpublished results). We therefore transfected the murine granulosa cell line, KK-1 (Kananen et al. 1995), with the Hsd17b1 5' deletion constructs described above. Though the fold activin A response was smaller than in L $\beta \mathrm{T} 2$ cells, the pattern of results was similar between the two cell types. That is, both basal and activin A promoter activities were lost with the truncation from -106 to -64 (Fig. 7A). As in L $\beta T 2$ cells, basal activity was significantly inhibited by SB431542 or Fst-288 (Fig. 7B).

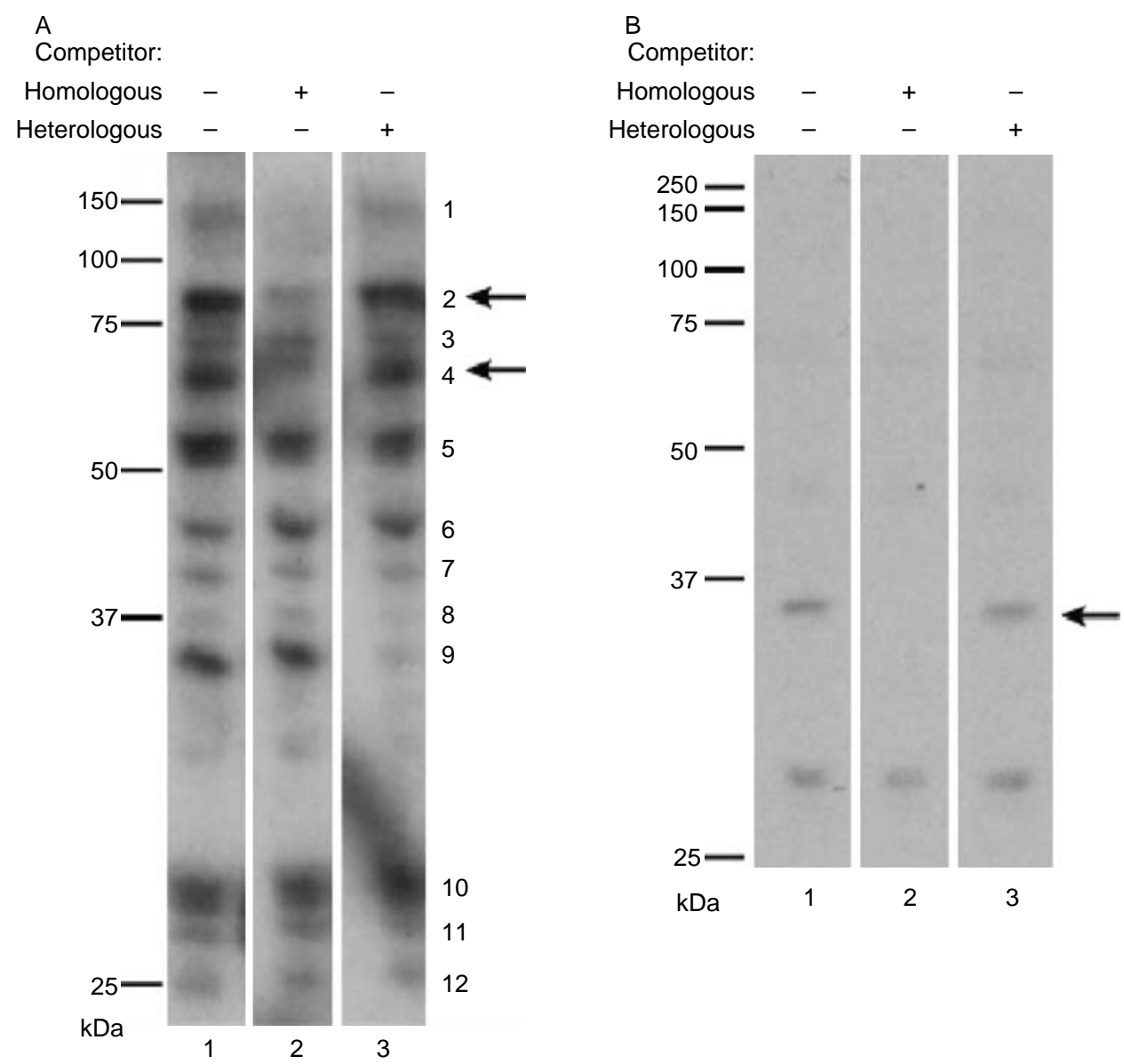

Figure 6 (A) L $\beta$ T2 nuclear protein fractions were collected after ion exchange chromatography and subjected to EMSA to identify fractions containing complex a/b-binding activity. These fractions were pooled, concentrated, and then used for southwestern blotting. Fractions were run in triplicate on SDSPAGE, transferred to nitrocellulose membranes, and renatured to determine approximate molecular weights of the binding proteins. Membranes were incubated with radio-labeled $-106 /-77$ Hsd17b1 probe alone (lane 1) or with 100-fold molecular excess of unlabeled homologous (lane 2, $-106 /-77$ Hsd17b1) or heterologous (lane 3, $-569 /-543$ Id3) probe. PolydldC was used as a nonspecific competitor. (B) The same analysis as described in (A) was repeated here, using L $\beta T 2$ nuclear protein fractions containing complex c-binding activity and ssDNA used as a nonspecific competitor. 
Finally, to determine whether the results observed in immortalized cells reflect regulation in non-transformed cells, we transfected primary murine granulosa cells with the Hsd17b1 5' deletion constructs and ALK4-T206D. Similar to what we observed in both KK-1 and L $\beta$ T2 cells, the promoter conferred significant basal reporter activity in primary cells, and this effect was lost with the truncation from -106 to -64 (Fig. 7C). Again, ALK4-T206D stimulated an increase in reporter activity in most of the reporters. However, where the stimulated response was lost between -106 and -64 in the cell lines, the effect was lost between -253 and -106 in primary cells (Fig. 7C).

\section{Discussion}

Activins regulate diverse aspects of reproductive function, and Fshb, Gnrhr, and Fst are established activin target genes in gonadotrope cells of the anterior pituitary. To identify other targets in these cells, we and others (Mazhawidza et al. 2006, Zhang et al. 2006) examined activin A-stimulated changes in gene expression in immortalized murine gonadotropes, L $\beta$ T2, using cDNA microarrays. We observed marked upregulation of Hsd17b1 expression, consistent with one of the earlier reports (Zhang et al. 2006). Here, we demonstrate that activin A regulates $H s d 17 b 1$ transcription in immediateearly fashion, downstream of the type I receptor ALK4, via SMAD2. SMAD4 appears critical for basal reporter activity, which is dependent upon endogenous signaling through ALK4/5/7, but is not required for the response to exogenous activin A (Fig. 4D). Basal and activin A-regulated activity appears to be independent of SMAD3, though we have previously demonstrated that activin A rapidly stimulates SMAD3 phosphorylation in these cells (Bernard 2004). We identified a minimal SBE within the activin A-responsive region of the promoter, which can interact with SMAD2 and SMAD2 $\Delta$ exon3. We have not yet determined whether these proteins are in complex together, but the DNA-affinity pulldown experiments suggest this may be the case. That is, the SBE can only bind one SMAD at a time, and yet both proteins were precipitated. In the case of full-length SMAD2, which does not bind DNA directly, partnering with SMAD2$\Delta$ exon3 most likely explains its association with the activinresponsive promoter fragment.

Four bp SBEs are common in the genome, and SMADs 3 and 4 (and SMAD2 $\Delta$ exon3) bind these sequences with low affinity (Shi et al. 1998). Therefore, SMAD-dependent signaling is thought to depend on the interactions of activated SMAD complexes with high-affinity DNA-binding partners that bind in the proximity of SBEs (Chen et al. 1996, 1997). Along these lines, we mapped two other cis-elements in the vicinity of the $\mathrm{SBE}$, which are required for basal and/or activin A-regulated activity. Biochemical analyses suggest that proteins of $\sim 85,68$, and $35 \mathrm{kDa}$ bind to one or more of these sites, though we have not yet determined their identities. Future analyses will characterize these proteins,

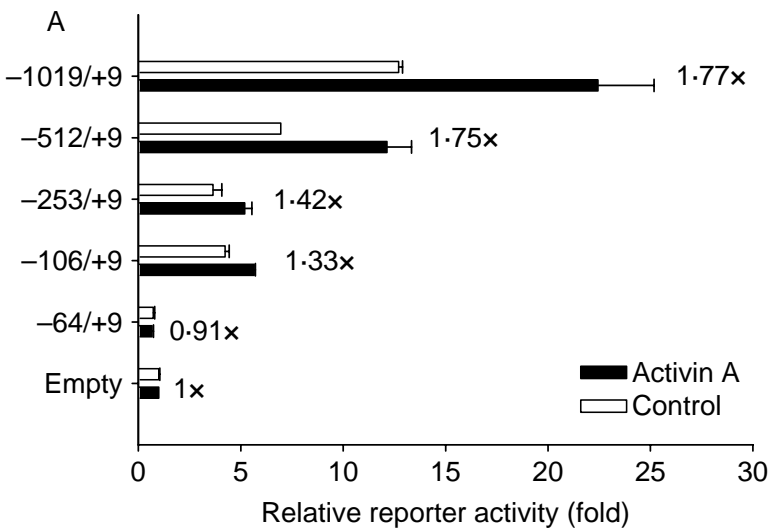

B
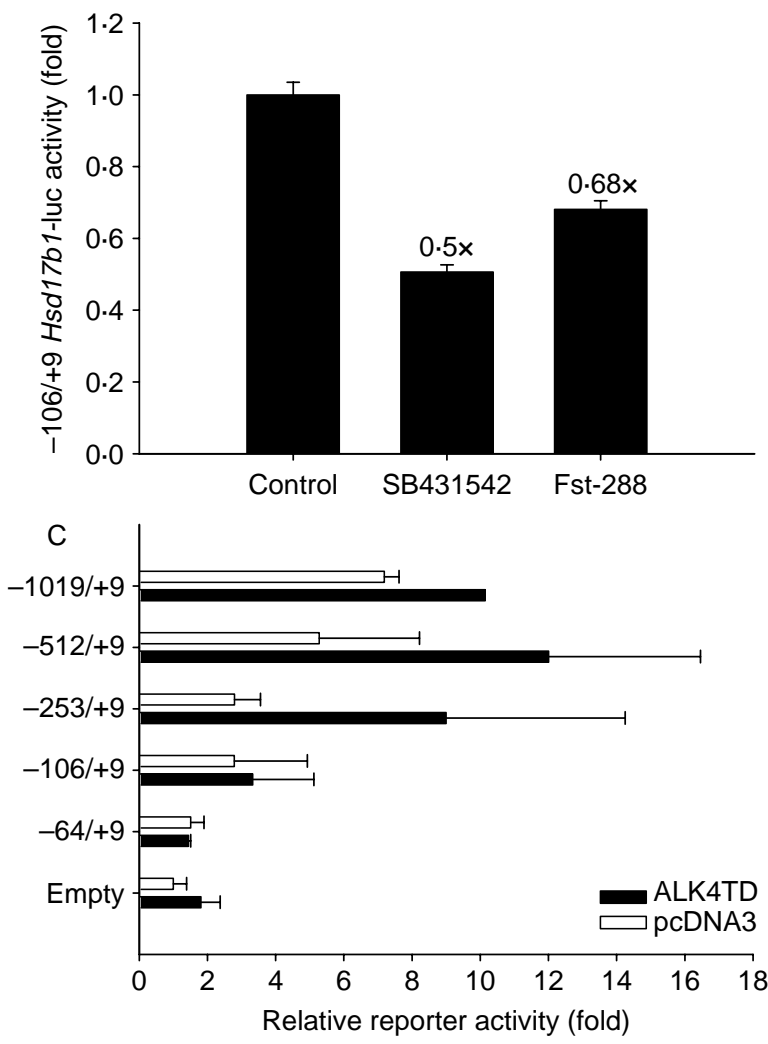

Figure 7 (A) KK1 cells were transfected with $450 \mathrm{ng} /$ well of the indicated murine $\mathrm{Hsd} 1 \mathrm{7b1-luc}$ promoter reporters, followed by $24 \mathrm{~h}$ treatment with activin A. Data show means of duplicates, normalized relative to $\mathrm{pGL3}$-Basic (empty) vector. The experiment was repeated thrice, with comparable results each time. (B) KK-1 cells were transfected with 450 ng/well of $-106 /+9$ Hsd17b1-luc reporter. Cells were then treated with $10 \mu \mathrm{M}$ SB431542 or $100 \mathrm{ng} / \mathrm{ml}$ follistatin for $24 \mathrm{~h}$. Treatments were performed in triplicate and data show the mean reporter activity relative to control set to 1. (C) Primary murine granulosa cells were transfected with $450 \mathrm{ng} /$ well of pGL3-Basic or the indicated Hsd17b1-luc reporters with $100 \mathrm{ng} /$ well of pcDNA3 or ALK4-T206D expression constructs. Cells were harvested the next day. Data show the mean (+s.D.) fold stimulation of duplicate samples relative to the empty vector/pcDNA3 condition. The data were compiled from four to five experiments. 
assess their roles in basal and activin A-regulated $H s d 17 b 1$ transcription, and their functional/physical interactions with SMAD proteins. Interestingly, the sequences mediating binding of complexes $\mathrm{a}, \mathrm{b}$, and $\mathrm{c}$, as well as the putative $\mathrm{SBE}$, are conserved in the human and rat HSD17B1/Hsd $7 b 1$ genes. In fact, in preliminary analyses, we observed that the human HSD17B1 proximal promoter is activin A responsive in L $\beta T 2$ cells (data not shown). Therefore, the mechanisms of activin A-regulated $H s d 17 b 1$ transcription observed here may be evolutionarily conserved.

Both the mRNA and protein analyses indicate a high basal level of $H s d 17 b 1$ gene expression in L $\beta T 2$ cells. Treatment with an inhibitor of ALK4 kinase activity or knockdown of SMAD4 both strongly inhibited basal promoter activity. SMAD2 knockdown did not inhibit basal activity, but the shRNA used targets of only full-length SMAD2 (Bernard 2004). Because these experiments were done in the absence of serum, the results suggest that a TGF $\beta$ superfamily ligand (or ligands) produced by the cells regulates Hsd17b1 expression in autocrine/paracrine fashion. The most obvious candidate is activin $\mathrm{B}$. We, and others, previously showed that these cells synthesize the Inhbb, but not Inhba, subunit, allowing them to produce activin $\mathrm{B}$, but not activin $\mathrm{A}$ or $\mathrm{AB}$ (Pernasetti et al. 2001, Lee et al. 2007, Antenos et al. 2008). Fst-288 or inhibin A, two known antagonists of activins, inhibited basal reporter activity similarly to the ALK4 inhibitor, further implicating activin $\mathrm{B}$ as the endogenous regulator in this system. However, recent data indicate that follistatins and inhibins can antagonize other TGF $\beta$ superfamily ligands (Wiater \& Vale 2003, Schneyer et al. 2008). Therefore, we cannot conclude definitively that endogenous activin $\mathrm{B}$ is the sole modulator of basal Hsd17b1 promoter activity. Future analyses are required to assess the full complement of TGF $\beta$ ligands expressed in these cells to determine the endogenous regulator(s).

Because L $\beta T 2$ cells are immortalized gonadotropes, it is important to assess whether the results gathered here reflect in vivo regulation of $H s d 17 b 1$. We confirmed the expression of the gene in both adult male and female murine pituitaries (data not shown), and $H s d 17 b 1 \mathrm{mRNA}$ is also detectable in purified murine gonadotropes (Gore and Miller, personal communication). Therefore, expression of the gene in a gonadotrope-like cell does not appear to be an artifact of the L $\beta$ T2 cell model. Still, we do not yet know whether it is similarly regulated by activins in gonadotropes in vivo and the difficulty of purifying gonadotropes complicates such analyses. However, activin A was previously shown to stimulate $H s d 17 b 1$ mRNA levels in primary rat granulosa cells (Ghersevich et al. 2000), and here we show that activin A and/or a constitutively active activin type I receptor, ALK4-T206D, stimulates $H s d 17 b 1$ promoter activity in immortalized and primary murine granulosa cells. Promoter deletions show that the promoter region $(-106 /-64)$ mediating basal reporter activity in L $\beta \mathrm{T} 2$ cells similarly mediates promoter activity in the granulosa cells. The same promoter region also mediates the exogenous activin
A/ALK4-T206D regulation of the gene in L $\beta$ T2 and KK-1 cells. In primary granulosa cells, however, the ALK4-T206Dresponsive region maps more distally to $-253 /-106$. Whether this reflects differences between transformed and non-transformed cells is not yet clear. However, there was significantly more variability in the primary than immortalized cells, leaving open the possibility that we may have missed ALK4-T206D regulation of the $-106 /+9$ reporter in the former.

A final obvious question is what role activin-regulated Hsd17b1 expression might be playing in gonadotrope cells in vivo. In granulosa cells, activins potentiate FSH-regulated (Suszko et al.) aromatase and $17 \beta-H S D 1$ activities, leading to increases in 17 $\beta$-estradiol synthesis (Xiao et al. 1990, Hillier \& Miro 1993, Ghersevich et al. 2000). Therefore, it is possible that activins might regulate $17 \beta$-estradiol synthesis in gonadotropes by potentiating the reduction of systemic estrone. Because estrogens inhibit gonadotropin production/secretion at the pituitary level (Glidewell-Kenney et al. 2008), this might form part of a negative feedback loop. That is, activins stimulate FSH production, which then stimulates (among other things) ovarian estrogen synthesis. Increased estrone may then travel to the pituitary where it is converted to the more active $17 \beta$-estradiol and thereby inhibits or attenuates further FSH synthesis and secretion. Indeed, activin A was shown to increase $\mathrm{L} \beta \mathrm{T} 2$ sensitivity to estrone as assessed by the activity of an estrogen-responsive reporter, ERE-tk-luc (Zhang et al. 2006). We similarly saw an activin A-induced increase in 17 $\beta$-HSD1 enzymatic activity in these cells. We therefore assessed the effects of estrogens on murine Fshb promoter reporter activity in the presence or absence of activin $A$, but neither estrone nor $17 \beta$-estradiol had any effects in these assays. This was the case in the presence or absence of co-transfected $\mathrm{ER} \alpha$ expression vector. Also, we were unable to replicate the results in Zhang et al. (2006) with ERE-tk-luc (data not shown). Recently, it was reported that some batches of $\mathrm{L} \beta \mathrm{T} 2$ cells are unresponsive to estrogens (Eertmans et al. 2007) and this seems to be the case with ours. Therefore, an assessment of the effects of activinregulated $H s d 17 b 1$ expression on gonadotropin synthesis must await an estrogen-sensitive batch of L $\beta$ T2 cells or a different cell system.

\section{Declaration of interest}

The authors have no conflict of interest to declare.

\section{Funding}

B B was supported by the National Science and Engineering Research Council of Canada (NSERC). The research was funded by NIH grants HD047794 (to D J B), HD050570 (to R-S G) and Program Project Grant HD91291 (to K E M), and Canadian Institutes of Health Research Grant MOP-89991 (to D J B). DJB is a chercheur-boursier of the Fonds de la recherche en Santé (FRSO). 


\section{Acknowledgements}

Our dear friend and collaborator, Matt Hardy, passed away unexpectedly during the preparation of this paper. We would like to dedicate this work in his memory. We greatly miss the passionate scientist and wonderful person he was.

The authors thank Dr Pamela Mellon and Dr Stephen Franks for generously providing L $\beta \mathrm{T} 2$ and KK-1 cells respectively, and Dr Elizabeth Roberston for the SMAD2 expression vector. Dr Greg Miller and Varin Gosein provided invaluable assistance with and instrumentation for ion exchange chromatography. We appreciate help from Dr Signe Kilen with animal breeding for primary granulosa cell collection and Erzsebet NagyKovacs for assistance in collection of pituitaries.

\section{References}

Antenos M, Zhu J, Jetly NM \& Woodruff TK 2008 An activin/furin regulatory loop modulates the processing and secretion of inhibin $\boldsymbol{\alpha}$ - and $\beta \mathrm{B}$-subunit dimers in pituitary gonadotrope cells. Journal of Biological Chemistry 283 33059-33068.

Attardi B \& Miklos J 1990 Rapid stimulatory effect of activin-A on messenger RNA encoding the follicle-stimulating hormone beta-subunit in rat pituitary cell cultures. Molecular Endocrinology 4 721-726.

Attisano L, Wrana JL, Montalvo E \& Massague J 1996 Activation of signalling by the activin receptor complex. Molecular and Cellular Biology 16 1066-1073.

Beattie GM, Lopez AD, Bucay N, Hinton A, Firpo MT, King CC \& Hayek A 2005 Activin A maintains pluripotency of human embryonic stem cells in the absence of feeder layers. Stem Cells 23 489-495.

Bernard DJ 2004 Both SMAD2 and SMAD3 mediate activin-stimulated expression of the follicle-stimulating hormone beta subunit in mouse gonadotrope cells. Molecular Endocrinology 18 606-623.

Bernard DJ, Lee KB \& Santos MM 2006 Activin B can signal through both ALK4 and ALK7 in gonadotrope cells. Reproductive Biology and Endocrinology 452

Blount AL, Vaughan JM, Vale WW \& Bilezikjian LMA 2008 SMAD-binding element in intron 1 participates in activin-dependent regulation of the follistatin gene. Journal of Biological Chemistry 283 7016-7026.

Burkart AD, Mukherjee A, Sterneck E, Johnson PF \& Mayo KE 2005 Repression of the inhibin alpha-subunit gene by the transcription factor CCAAT/enhancer-binding protein-beta. Endocrinology 146 1909-1921.

Calkhoven CF, Bouwman PR, Snippe L \& Ab G 1994 Translation start site multiplicity of the CCAAT/enhancer binding protein alpha mRNA is dictated by a small 5' open reading frame. Nucleic Acids Research 22 $5540-5547$.

Chen X, Rubock MJ \& Whitman M 1996 A transcriptional partner for MAD proteins in TGF-beta signalling. Nature 383 691-696.

Chen X, Weisberg E, Fridmacher V, Watanabe M, Naco G \& Whitman M 1997 SMAD4 and FAST-1 in the assembly of activin-responsive factor. Nature 389 85-89.

Corrigan AZ, Bilezikjian LM, Carroll RS, Bald LN, Schmelzer CH, Fendly BM, Mason AJ, Chin WW, Schwall RH \& Vale W 1991 Evidence for an autocrine role of activin $\mathrm{B}$ within rat anterior pituitary cultures. Endocrinology 128 1682-1684.

Dennler S, Huet S \& Gauthier JM 1999 A short amino-acid sequence in MH1 domain is responsible for functional differences between SMAD2 and SMAD3. Oncogene 18 1643-1648.

DePaolo LV, Bald LN \& Fendly BM 1992 Passive immunoneutralization with a monoclonal antibody reveals a role for endogenous activin-B in mediating FSH hypersecretion during estrus and following ovariectomy of hypophysectomized, pituitary-grafted rats. Endocrinology 130 1741-1743.

Derynck R \& Zhang YE 2003 SMAD-dependent and SMAD-independent pathways in TGF-beta family signalling. Nature 425 577-584.

Eertmans F, Willem D, Olivier de W, Wim VB, Veerle B, Marc B, Guy H, Frank C \& Jean-Marc K 2007 Estrogen receptor signaling is an unstable feature of the gonadotropic LbetaT2 cell line. Molecular and Cellular Endocrinology 273 16-24.
Farre D, Roset R, Huerta M, Adsuara JE, Rosello L, Alba MM \& Messeguer X 2003 Identification of patterns in biological sequences at the ALGGEN server: PROMO and MALGEN. Nucleic Acids Research 31 3651-3653.

Fernandez-Vazquez G, Kaiser UB, Albarracin CT \& Chin WW 1996 Transcriptional activation of the gonadotropin-releasing hormone receptor gene by activin A. Molecular Endocrinology 10 356-366.

Ghersevich S, Akinola L, Kaminski T, Poutanen M, Isomaa V \& Vihko R 2000 Activin-A, but not inhibin, regulates 17beta-hydroxysteroid dehydrogenase type 1 activity and expression in cultured rat granulosa cells. Journal of Steroid Biochemistry and Molecular Biology 73 203-210.

Glidewell-Kenney C, Weiss J, Hurley LA, Levine JE \& Jameson JL 2008 Estrogen receptor alpha signaling pathways differentially regulate gonadotropin subunit gene expression and serum follicle-stimulating hormone in the female mouse. Endocrinology 149 4168-4176.

Harrison CA, Gray PC, Vale WW \& Robertson DM 2005 Antagonists of activin signaling: mechanisms and potential biological applications. Trends in Endocrinology and Metabolism 16 73-78.

Hillier SG \& Miro F 1993 Local regulation of primate granulosa cell aromatase activity. Journal of Steroid Biochemistry and Molecular Biology 44 435-439.

Itoh S, Thorikay M, Kowanetz M, Moustakas A, Itoh F, Heldin CH \& ten Dijke 2003 Elucidation of SMAD requirement in transforming growth factor-beta type I receptor-induced responses. Journal of Biological Chemistry 278 3751-3761.

Kananen K, Markkula M, Rainio E, Su JG, Hsueh AJ \& Huhtaniemi IT 1995 Gonadal tumorigenesis in transgenic mice bearing the mouse inhibin alphasubunit promoter/simian virus T-antigen fusion gene: characterization of ovarian tumors and establishment of gonadotropin-responsive granulosa cell lines. Molecular Endocrinology 9 616-627.

Kipp JL, Kilen SM, Woodruff TK \& Mayo KE 2007 Activin regulates estrogen receptor gene expression in the mouse ovary. Journal of Biological Chemistry 282 36755-36765.

Lamba P, Santos MM, Philips DP \& Bernard DJ 2006 Acute regulation of murine follicle-stimulating hormone beta subunit transcription by activin A. Journal of Molecular Endocrinology 36 201-220.

Laping NJ, Grygielko E, Mathur A, Butter S, Bomberger J, Tweed C, Martin W, Fornwald J, Lehr R, Harling J et al. 2002 Inhibition of transforming growth factor (TGF)-beta1-induced extracellular matrix with a novel inhibitor of the TGF-beta type I receptor kinase activity: SB-431542. Molecular Pharmacology 62 58-64.

Lee KB, Khivansara V, Santos MM, Lamba P, Yuen T, Sealfon SC \& Bernard DJ 2007 Bone morphogenetic protein 2 and activin A synergistically stimulate follicle-stimulating hormone beta subunit transcription. Journal of Molecular Endocrinology 38 315-330.

Ling N, Ying SY, Ueno N, Shimasaki S, Esch F \& Guillemin R $1986 a$ Pituitary FSH is released by a heterodimer of the beta-subunits from the two forms of inhibin. Nature 321 779-782.

Ling N, Ying SY, Ueno N, Shimasaki S, Esch F, Hotta M \& Guillemin R $1986 b$ A homodimer of the beta-subunits of inhibin A stimulates the secretion of pituitary follicle stimulating hormone. Biochemical and Biophysical Research Communications 138 1129-1137.

Matzuk MM, Kumar TR, Shou W, Coerver KA, Lau AL, Behringer RR \& Finegold MJ 1996 Transgenic models to study the roles of inhibins and activins in reproduction, oncogenesis, and development. Recent Progress in Hormone Research 51 123-154 (discussion 155-127).

Mazhawidza W, Winters SJ, Kaiser UB \& Kakar SS 2006 Identification of gene networks modulated by activin in LbetaT2 cells using DNA microarray analysis. Histology and Histopathology 21 167-178.

Messeguer X, Escudero R, Farre D, Nunez O, Martinez J \& Alba MM 2002 PROMO: detection of known transcription regulatory elements using species-tailored searches. Bioinformatics 18 333-334.

Pernasetti F, Vasilyev VV, Rosenberg SB, Bailey JS, Huang HJ, Miller WL \& Mellon PL 2001 Cell-specific transcriptional regulation of folliclestimulating hormone-beta by activin and gonadotropin-releasing hormone in the LbetaT2 pituitary gonadotrope cell model. Endocrinology 142 2284-2295.

Reis FM, Luisi S, Carneiro MM, Cobellis L, Federico M, Camargos AF \& Petraglia F 2004 Activin, inhibin and the human breast. Molecular and Cellular Endocrinology 225 77-82. 
Roberts V, Meunier H, Vaughan J, Rivier J, Rivier C, Vale W \& Sawchenko P 1989 Production and regulation of inhibin subunits in pituitary gonadotropes. Endocrinology 124 552-554.

Schneyer AL, Sidis Y, Gulati A, Sun JL, Keutmann H \& Krasney PA 2008 Differential antagonism of activin, myostatin and growth and differentiation factor 11 by wild-type and mutant follistatin. Endocrinology 149 4589-4595.

Shi Y, Wang YF, Jayaraman L, Yang H, Massague J \& Pavletich NP 1998 Crystal structure of a SMAD MH1 domain bound to DNA: insights on DNA binding in TGF-beta signaling. Cell 94 585-594.

Singh A \& Reed MJ 1991 Insulin-like growth factor type I and insulin-like growth factor type II stimulate oestradiol-17 beta hydroxysteroid dehydrogenase (reductive) activity in breast cancer cells. Journal of Endocrinology 129 R5-R8.

Suszko MI, Lo DJ, Suh H, Camper SA \& Woodruff TK 2003 Regulation of the rat follicle-stimulating hormone beta-subunit promoter by activin. Molecular Endocrinology 17 318-332.

Tsuchida K, Nakatani M, Yamakawa N, Hashimoto O, Hasegawa Y \& Sugino H 2004 Activin isoforms signal through type I receptor serine/threonine kinase ALK7. Molecular and Cellular Endocrinology 220 59-65.

Vale W, Rivier J, Vaughan J, McClintock R, Corrigan A, Woo W, Karr D \& Spiess J 1986 Purification and characterization of an FSH releasing protein from porcine ovarian follicular fluid. Nature 321 776-779.

Weiss J, Guendner MJ, Halvorson LM \& Jameson JL 1995 Transcriptional activation of the follicle-stimulating hormone beta-subunit gene by activin. Endocrinology 136 1885-1891.

Werner S \& Alzheimer C 2006 Roles of activin in tissue repair, fibrosis, and inflammatory disease. Cytokine and Growth Factor Reviews 17 $157-171$.
Wiater E \& Vale W 2003 Inhibin is an antagonist of bone morphogenetic protein signaling. Journal of Biological Chemistry 278 7934-7941.

Xiao S, Findlay JK \& Robertson DM 1990 The effect of bovine activin and follicle-stimulating hormone (FSH) suppressing protein/follistatin on FSHinduced differentiation of rat granulosa cells in vitro. Molecular and Cellular Endocrinology 69 1-8.

Xu RH, Sampsell-Barron TL, Gu F, Root S, Peck RM, Pan G, Yu J, Antosiewicz-Bourget J, Tian S, Stewart R et al. 2008 NANOG is a direct target of TGFbeta/activin-mediated SMAD signaling in human ESCs. Cell Stem Cell 3 196-206.

Yagi K, Goto D, Hamamoto T, Takenoshita S, Kato M \& Miyazono K 1999 Alternatively spliced variant of SMAD2 lacking exon 3. Comparison with wild-type SMAD2 and SMAD3. Journal of Biological Chemistry 274 703709.

Yaneva M \& Tempst P 2006 Isolation and mass spectrometry of specific DNA binding proteins. Methods in Molecular Biology 338 291-303.

Zhang H, Bailey JS, Coss D, Lin B, Tsutsumi R, Lawson MA, Mellon PL \& Webster NJ 2006 Activin modulates the transcriptional response of LbetaT2 cells to gonadotropin-releasing hormone and alters cellular proliferation. Molecular Endocrinology 20 2909-2930.

Received in final form 22 December 2008

Accepted 9 January 2009

Made available online as an Accepted Preprint

9 January 2009 